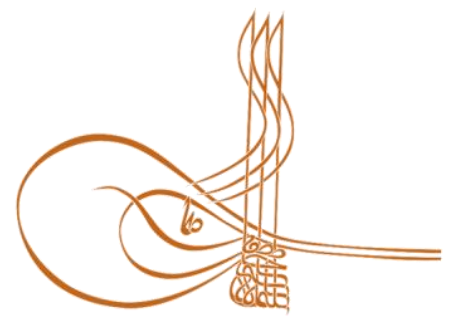

www.turkishstudies.net/economy
Turkish Studies - Economics, Finance, Politics

eISSN: 2667-5625

Research Article / Araştırma Makalesi

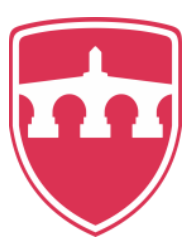

INTERNATIONAL BALKAN

UNIVERSITY

Sponsored by IBU

\title{
Planlı Davranış Teorisi Perspektifinden Girişimcilik Niyeti Üzerinde Sosyal Sermaye Öz Yeterlilik ve Öz Saygının Rolü
}

\author{
The Role of Social Capital Self-Efficacy and Self-Esteem on the Entrepreneurship Intention From \\ the Perspective of Planned Behaviour Theory
}

\author{
Metin Işık* - Berat Çiçek ${ }^{* *}$
}

\begin{abstract}
In this study, the role of self-efficacy, self-esteem and bridging social capital on entrepreneurial intention was examined. The relationship of these notions to each other has been demonstrated by many studies in the literature. However, no research evaluates all these notions with a holistic view. In this respect, these variables were examined holistically. High self-esteem and self-efficacy perception increase individual's self-confidence, competence and sufficiency belief. This belief strengthens the social aspect of the individual and paves the way for him/her to have an entrepreneurial personality. Besides, the individual's bridging of social capital directly affects the individual's intention to entrepreneurship. In this context, the relationship of these variables with each other was tested in terms of moderation and mediation. The research was carried out with the data obtained from the students of business administration of 17 state universities in Eastern Anatolia Region. Firstly, the effect of bridging social capital on entrepreneurial intention and selfefficacy was tested in the study. As a result of the analysis; bridging social capital positively affected both entrepreneurial intention and self-efficacy. Then, the effect of self-efficacy on entrepreneurial intention was analysed and it was found that self-efficacy had a positive effect on entrepreneurial intention. As a result of the study, it was found that self-esteem affects entrepreneurship intention. Moreover, it was concluded that entrepreneurship intention expanded when self-esteem increased. In addition, self-esteem moderates and strengthen the positive relationship between self-efficacy and entrepreneurial intention. As a result of the analyses conducted on the mediating effect of self-efficacy between bridging social capital and entrepreneurial intention; self-efficacy has been found to have a mediating effect in this relationship. At the end of the paper, suggestions were made to university administrations, students and researchers.
\end{abstract}

\footnotetext{
* Dr. Öğr. Üyesi, Bitlis Eren Üniversitesi, İktisadi ve İdari Bilimler Fakültesi, İşletme Bölümü Asst. Prof. Dr., Bitlis Eren University, Faculty of Economics and Administrative Sciences, Department of Business ORCID 0000-0003-4577-0095

beu.metin@gmail.com

** Dr. Öğr. Üyesi, Muş Alparslan Üniversitesi, İktisadi ve İdari Bilimler Fakültesi, İşletme Bölümü

Asst. Prof. Dr., Muş Alparslan University, Faculty of Economics and Administrative Sciences, Department of Business ORCID 0000-0002-4584-5862

b.cicek@alparslan.edu.tr

Cite as/ Atıf: Işık, M., Çiçek, B. (2020). Planlı davranış teorisi perspektifinden girişimcilik niyeti üzerinde sosyal sermaye öz yeterlilik ve öz saygının rolü, Turkish Studies - Economy, 15(1), 185-206. https://dx.doi.org/10.29228/TurkishStudies.39894

Received/Geliş: 25 November/Kasım 2019

Accepted/Kabul: 25 March/Mart 2020

Copyright $(\mathcal{C}$ INTAC LTD, Turkey

Checked by plagiarism software

Published/Yayın: 30 March/Mart 2020

CC BY-NC 4.0
} 
Structured Abstract: Background- In this study, we examined the role of social capital, self-efficacy, and self-esteem on entrepreneurial intention. Entrepreneurship draws attention as a leading factor in economic growth, providing high employment, strong job creation and positive social development. Entrepreneurship is quite important for emerging economies because entrepreneurs can create value for the individual and society, respond to economic opportunities, and even initiate a process that causes sociological changes in the economic system with the innovations it brings. In this context, entrepreneurship is very important, and it is considered worthy of continuous examination in the literature.

Researches on entrepreneurship usually focus on the factors that push individuals into entrepreneurship. In this study, we discussed the factors that affect entrepreneurship intentions from different perspectives. In this context, we examined the direct effects of social capital on the entrepreneurial intention, and the indirect effects of self-efficacy and self-esteem. The relationship of these notions to each other has been demonstrated by many studies in the literature. However, no research evaluates all these notions with a holistic view. In this respect, we examined these notions holistically.

As a dynamic of the concept of social capital, universities have an important place in the education and training life of the individuals. Because universities are the institutions where the "interaction" phenomenon that forms the basis of social capital occurs most effectively. Therefore, social capital is considered as a variable that can directly affect entrepreneurial intention.

Conceptual and empirical findings of previous studies in the literature revealed that self-efficacy and self-esteem affect entrepreneurship. Thus, we examined the effects of these two variables on entrepreneurial intention.

Research Design- High self-esteem and self-efficacy perception increase individual's selfconfidence, competence and sufficiency belief. This belief strengthens the social aspect of the individual and paves the way for him/her to have an entrepreneurial personality. Besides, the individual's bridging of social capital directly affects the individual's intention to entrepreneurship. In this context, the relationship of these variables with each other was tested in terms of moderation and mediation.

We thought that the variables within the scope of the research could be applied and tested in the best way on university students due to variables' theoretical structure. In this regard, we conducted research on university students. The data obtained were analyzed with the MPlus 8.3 program according to the two-step structural equation modeling approach by Anderson and Gerbing (1988), which consists of analyzing the data and testing hypotheses.

Measurement Tools- In order to collect data for the research, we conducted a survey study with the business school students of the universities in the Eastern Anatolia Region in Turkey. The questionnaire form, which was created to collect data, consisted of five sections as well as a cover page stating the concept of the study, privacy issues and participation was voluntary. In the first part of the questionnaire form, questions were asked to learn the demographic information of the participants. In the second part, bridging social capital scale consisting of 8 items developed by Steinfield, Ellison, and Lampe (2008) was used. In the third part, the self-esteem scale used by Steinfield, Ellison, and Lampe (2008) in the same study as the bridging social capital was used. The fourth part of the survey included the self-efficacy scale developed by Schwarzer, Mueller, and Greenglass (1999).

Results- In the first phase of the analysis, the variables were confirmed to have good validity and reliability. Then we proceeded to the test of hypotheses. Hypothesis testing results: Firstly, the effect of bridging social capital on entrepreneurial intention and self-efficacy was tested in the study. As a result of the analysis; bridging social capital positively affected both entrepreneurial intention and self-efficacy. Then, the effect of self-efficacy on entrepreneurial intention was analyzed and it was found that self-efficacy had a positive effect on entrepreneurial intention. As a result of the study, it was found that self-esteem affects entrepreneurship intention. Moreover, it was concluded that entrepreneurship intention expanded when selfesteem increased. In addition, self-esteem moderates and strengthen the positive relationship between selfefficacy and entrepreneurial intention. As a result of the analyses conducted on the mediating effect of selfefficacy between bridging social capital and entrepreneurial intention; self-efficacy has been found to have a mediating effect in this relationship.

Suggestions- At the end of the research, we suggested that university administrations and related policymakers include educational practices for educating individuals with high self-efficacy and an 
entrepreneurial spirit who have self-confidence and self-esteem. We also suggested that researchers test the variables of this study in different cultures and compare private and public universities.

Keywords: Entrepreneurship Intention, Bridging Social Capital, Self-Efficacy, Self-Esteem, Planned Behavior Theory

Öz: Bu araştırmada, öz yeterlik, öz saygı ve köprüleyici sosyal sermayenin girişimcilik niyeti üzerindeki rolü incelenmiştir. $\mathrm{Bu}$ kavramların birbirleriyle olan ilişkisi literatürdeki birçok araştırma tarafından kanıtlanmıştır. Ancak bu kavramların hepsini bütüncül olarak değerlendiren araştırmaya rastlanmamıştır. Bu bakımdan araştırmada bu değişkenler bütüncül olarak incelenmiştir. Bireyin kendisine yönelik yüksek öz saygı (benlik saygısı) ile öz yeterlilik algısı, kişinin güven, yeterlilik ve yetkinlik inancını artırmaktadır. Bu inanç da bireyin sosyal yönünü güçlendirmekte ve onun girişimci bir kişiliğe sahip olmasına zemin hazırlamaktadır. Bunlarla birlikte, bireyin sosyal sermayeyi köprülemesi de bireyin girişimcilik niyetini doğrudan etkilemektedir. Bu bağlamda, araştırmada bu değişkenlerin birbirleriyle olan ilişki düzenleyicilik ve aracılık yönünden test edilmiştir. Araştırma, Doğu Anadolu Bölgesindeki 17 devlet üniversitesinin işletme bölümü öğrencilerinden elde edilen veriler ile gerçekleştirilmiştir. Araştırmada öncelikle köprüleyici sosyal sermayenin girişimcilik niyeti ve öz yeterlilik üzerindeki etkisi test edilmiştir. Analiz sonucunda; köprüleyici sosyal sermayenin hem girişimcilik niyetini hem de öz yeterliliği pozitif yönlü etkilediği görülmüştür. Daha sonra, öz yeterliliğin girişimcilik niyeti üzerindeki etkisi test edilmiş ve öz yeterliliğin girişimcilik niyeti üzerinde pozitif bir etkiye sahip olduğu bulgulanmıştır. Araştırmada bir diğer sonuç olarak öz saygının girişimcilik niyetini etkilediği tespit edilmiştir. Analizlerde öz saygının arttığı durumlarda girişimcilik niyetinin arttı̆̆ı sonucuna varılmıştır. Ayrıca öz saygının, öz yeterlilik ile girişimcilik niyeti arasındaki pozitif ilişkiyi düzenlediği ve güçlendirdiği görülmüștür. Öz yeterliliğin köprüleyici sosyal sermaye ve girişimcilik niyeti arasındaki aracı etkisine yönelik yapılan analizler neticesinde; öz yeterliliğin bu ilişkide aracı etkiye sahip olduğu tespit edilmiştir. Araştırma sonunda üniversite yönetimleri, öğrencilere ve araştırmacilara önerilerde bulunulmuştur.

Anahtar Kelimeler: Girişimcilik Niyeti, Köprüleyici Sosyal Sermaye, Öz Yeterlilik, Öz Saygı, Planlı Davranış Teorisi

\section{Giriş}

Ekonomik büyüme, yüksek istihdam, güçlü iş yaratma ve olumlu sosyal gelişim sağlamada öncü bir faktör olarak dikkat çeken girişimcilik, son yıllarda her zamanki öneminden daha da önemli bir hale gelmiştir (Acs vd., 2005), çünkü girişimciler birey ve toplum için değer yaratabilir, ekonomik firsatlara cevap verebilir, hatta getirdiği yeniliklerle ekonomik sistem içerisinde sosyolojik değișikliklere neden olan bir süreci başlatabilirler (Çiçek, 2018; Muzyka vd., 1995). Buna rağmen girişimciliğe olan rağbet oldukça azdır (Liñán vd., 2011). Örneğin OECD ülkelerinde girişimcilik faaliyetlerine yetişkin nüfusunun \%10'undan dahi az bir oranda bireyin başladığı rapor edilmiştir (Athiyaman vd., 2007). Bu nedenle bireylerin girişimcilik niyetleri literatürde oldukça sık tartışlan bir konu durumundadır.

Konuyla ilgili literatürdeki ilk çalışmalardan sayılabilecek McClelland'ın (1962) çalışmasına göre; girişimciliğe ait özelliklerin doğuştan geldiği savunulmuştur. Fakat bu duruma karşıt görüşler zaman içerisinde daha kabul görür hale gelmiştir. Böylelikle girişimciliği etkileyen unsurlar olarak eğitim (Çiçek, 2016; Katz, 2003; Kuratko, 2005; McMullan ve Gillin, 2001; Oosterbeek vd., 2010), kişilik özellikleri (Baum vd., 2014; Brandstätter, 2011; Rauch ve Frese, 2007) ve çevresel koşullar (Acs ve Audretsch, 2003; Schmitt-Rodermund, 2004) ön plana çıkmıştır.

Ajzen'in (1991) planlı davranışlar teorisinden sonra girişimcilik niyetini ortaya koymaya yönelik çalışmalar hız kazanmaya başlamıştır. Böylece çalışmalar iki gruba yoğunlaşmıştır. Bunlar, potansiyel girişimciler (Davidsson, 1991) ve hali hazırda girişimci olan bireylerdir (Krueger ve Carsrud, 1993). Bu iki grubun girişimcilik kariyerini tercih etmesinin ardında, kişilik özellikleri ve 
çevresel koşulların durumu ampirik olarak test edilmeye başlanmıştır. Bu çalışmada ise potansiyel girişimci adayları olan üniversite öğrencilerine yoğunlaşılmıştır. Bu bağlamda öncelikle üniversite öğrencilerinin edindikleri sosyal sermayenin girişimcilik niyetleri üzerindeki etkisi ortaya konulmaya çalışılmıştır. Çevresel faktörler içerisinden sosyal sermayenin seçilmesinin temel sebebi, sosyal sermayenin hem makro (toplumsal) düzeyde (Putnam vd., 1993) hem de mikro (firma ve birey) düzeyde (Barros ve Alves, 2003) ekonomik başarı için önemli bir role sahip olmasidir.

İlhan (2003) girişimciliği etkileyen tek bir unsur olamayacağını belirtmiş̧ir. Ayrıca içsel ve çevresel faktörlerin bir arada bireyleri girişimciliğe ittiğinin altını çizmiştir. Bu bağlamda sadece çevresel koşullara yönelmekten ziyade bireyin kişilik özelliklerinin girişimcilik niyeti üzerindeki etkisinin de ortaya konulması amaçlanmıştır. Bu amaç doğrultusunda girişimciliği etkileyen faktörlerden olan öz yeterlilik ve öz saygı değişkenlerinin de girişimcilik niyeti üzerindeki etkisinin ortaya konulması hedeflenmiştir. Öz yeterlilik terimi, Bandura'nın (1977) sosyal öğrenme teorisinden türetilmiştir. Zaman içerisinde girişimcilik niyeti üzerindeki önemli etkisiyle birlikte girişimcilik alanında yoğun bir biçimde irdelenmeye başlamıştır. Bu önemine binaen bireyin öz yeterlilik algısının girişimcilik niyeti üzerindeki etkisi ortaya konulmak istenmiştir.

Özsaygı araştırmanın bir diğer değişkenidir. Girişimcilerin benlik saygısı ile ilgili bulgular karışık olmakla birlikte, literatürdeki kanıtlar girişimcilerin genellikle becerilerine, yeteneklerine ve maharetlerine büyük önem verdiklerini göstermiştir. Bu durum girişimcilik niyeti açısından özsaygının altını çizmiştir. Çoğu çalışmada bireylerin ve özellikle öğrencilerin sahip oldukları özsaygının girişimcilik niyetini etkilediği ampirik olarak kanıtlanmıştır (Sexton ve Bowman, 1983, 1984).

$\mathrm{Bu}$ çalışmada planlı davranış teorisi perspektifinden, üniversitenin öğrencilere sunduğu sosyal sermayenin öğrencilerin girişimci olma niyetleri üzerindeki etkisi ve bu iki değişken arasındaki ilişkide öz yeterliliğin aracı rolünün ortaya konulması amaçlanmıştır. Ayrıca öz yeterlilik ile girişimcilik niyeti arasındaki ilişkide öz saygının düzenleyicilik etkisinin tespit edilmesi amaçlanmıştır. Bu amaç doğrultusunda Doğu Anadolu Bölgesi'ndeki üniversitelerin işletme bölümü öğrencileri ile bir anket çalışması gerçekleştirilmiştir.

\section{Girişimcilik Niyeti}

İlk defa Ajzen $(1988,1991)$ tarafından kullanılan planlı davranış teorisi, bireylerin belirli bir davranışı gerçekleştirme niyetini açıklamak için kullanılan bir teoridir. Teoriye göre niyet, planlanan davranışı gerçekleştirmek için insanların ne kadar zorlamak istediklerinin ve ne kadar çaba göstermeyi planladıklarının bir göstergesidir (Ajzen ve Driver, 1992). Yapılan çeşitli araştırmalar, planlı davranış teorisinin bir niyeti (özelde girişimcilik niyetini) açıklamada oldukça başarılı olduğunu savunmuşlardır (Ajzen ve Driver, 1992; Krueger, Reilly ve Carsrud, 2000; van Gelderen vd., 2008). Buradan hareketle bu çalışmada girişimcilik niyeti planlı davranış modeliyle açıklanmaya çalışılmıştır. Bu modele göre girişimciliğe yönelik niyetin üç bağımsız belirleyicisi; girişimciliğe yönelik tutumlar, öznel normlar ve algılanan davranış kontrolüdür (Ajzen, 1991).

Modele göre tutumlar, bir davranışı gerçekleştirmeye yönelik bireylerin sahip oldukları tutumu ifade etmektedir. Başka bir deyişle davranışı gerçekleştirmeye yarayan kişisel arzu algılarıdır (Ajzen, 1988). Girişimcilik durumunda ise kişilerin girişimciliğe yönelik tutumları onların girişimci olma konusundaki kişisel istekliliğini ifade etmektedir (Kolvereid, 1996). Bu nedenle, kendi işinin sahibi olma konusundaki yüksek beklenti ve inançlar girişimciliğe yönelik olumlu bir tutumu yansıtmaktadır. Burada genelde bireye yakın olan insanlar, örneğin; aile, akranlar, eş, yakın arkadaş, öğretmenler ve bireyin hayatında önemli olduğunu düşündüğü herhangi birisi bu normun oluşmasında etkili olabilmektedir (Ariff vd., 2010).

Algılanan davranış kontrolü ise algılanan hedef davranışı yürütme yeteneğini yansıtmaktadır (Ajzen, 1988). Bu kontrol bireyin böyle bir davranışı gerçekleştirmedeki kolaylık 
ve zorluk derecesine ilişkin algısı ile ilgilidir ve öngörülen engellerin yanı sıra geçmiş deneyimleri de yansıttığ1 varsayılmaktadır (Ajzen ve Driver, 1992). Bu yapı, davranış1 gerçekleştirmek için gerekli becerilere, kaynaklara ve firsatlara erişim algılarından etkilenir. Başka bir deyişle bir birey durumsal faktörler üzerinde kontrol sahibi olduğunu hissediyorsa, belirli bir davranış1 gerçekleştirme niyetini geliştirebilir (Ariff vd., 2010).

Planlı davranış modelindeki öznel normlar, kişinin söz konusu davranışı gerçekleștirme veya onun karşısına çıkmasına yönelik toplumsal baskı algısını ifade etmektedir. Spesifik olarak öznel norm, bireyin önemli kişilerin çoğu davranış1 gerçekleştirmemesi gerektiğini düşündüğü algısından ibarettir (Ajzen, 1991). Model, öznel normun inançların bir işlevi olduğunu ileri sürmektedir. Eğer bir birey, referanslarının bir davranışın yapılması gerektiğini düşündügüne inanıyorsa, öznel norm bu davranışı yapma niyetini etkileyecektir.

Planlı davranış modeline göre girişimciliğe yönelik tutumlar; özerklik, rekabetçilik, refah, zenginlik, finansal güvenlik ihtiyacı, iş yükünden kaçınma vb. olabilmektedir. Algılanan davranış kontrolü ise azim, girişimci zekâsı, öz yeterlilik, öz sayg1, yaratıcılık gibi değişkenlerden oluşmaktadır. Öznel normlar ise aile, çevre, sosyal sermaye gibi bireyleri girişimciliğe iten faktörlerden oluşmaktadır (van Gelderen vd., 2008). Bu çalışmada girişimcilik niyetini belirleyen faktörler olarak sosyal sermaye, öz yeterlilik ve öz saygı seçilmiştir. Bu değişkenlerin girişimcilik niyetini belirleyeceğine dair en uygun teori planlı davranış teorisidir. Bu nedenle çalışma planlı davranış perspektifinden ele alınmıştır.

\section{Sosyal Sermaye}

Sosyal sermaye kavramı başlangıçta topluluk (community) çalışmalarında ortaya çıkmıştır. Kavram, zaman içinde geliştirilen güçlü kişisel ilişki ağlarının şehir mahallelerinin hayatta kalması ve işleyişi için merkezi önemini vurgulayarak, bu tür topluluklarda güven, işbirliği ve kolektif eylem için temel sağlamıştır (Jacobs, 1965; Nahapiet ve Ghoshal, 1998). Sosyal sermaye teorisinin merkezi önermesi, ilişki ağlarının üyelerine kendilerine kredi vermeye hak sağlayan bir kolektivite sermayesi olduğu ve sosyal ilişkilerin yürütülmesi için değerli bir kaynak oluşturmasına dayanmaktadır. $\mathrm{Bu}$ bakımdan sosyal sermaye karşılıklı tanışma ve tanınma ağları içine yerleştirilmiştir (Bourdieu, 1986). Aslından sosyal sermaye, bir bireyin başkalarıyla olan ilişsisinde elde ettiği faydayı açıklamak için kullanılan elastik bir kavramdır (Adler ve Kwon, 2002). Sosyal sermaye iki veya daha fazla birey arasında işbirliğini teşvik eden somutlaştırılmış gayri resmi bir normdur (Fukuyama, 2001). Bourdieu ve Wacquant'a (1992) göre sosyal sermaye, az veya daha fazla kurumsallaşmış karşılıklı tanışma ve tanınma ilişkileri arasında kalıcı bir ağa sahip olmaları nedeniyle, bir bireye veya bir gruba tahakkuk eden kaynakların toplamı olarak tanımlamışlardır. Coleman (1988) ise sosyal sermayeyi, geniş anlamda insanlar arasındaki ilişkiler yoluyla biriken kaynaklar olarak tanımlamaktadır. Dolayısıyla sosyal sermayenin sivil bir topluluk ve sosyal yapı içinde bulunana bireylerin birbirileriyle olan ilişkilerine odaklandığı söylenebilir (Halpern, 2005).

Sosyal sermaye literatürde bağlayıcı (bonding) ve köprüleyici (bridging) şeklinde sınıflandırıldığı görülmektedir. Bağlayıcı sosyal sermaye, aile, yakın arkadaş ve komşu gibi sıkı sıkıya bağlı, birbirini tanıyan, duygusal açıdan yakın ilişkide bulunan bireyler arasında bulunur (Ellison vd., 2007; Yılmaz ve Meçik, 2017). Aile, arkadaşlar ve komşu gibi yakın bağlar arasındaki ilişkileri ifade eden bağlayıcı sosyal sermaye, türdeş gruplar içerisindeki ilişkilerle ilgilidir. Bu ilişkiler, sosyal normların aile bireylerine aktarımı, uygun sosyal davranışların kazanılması, dayanışmanın tesis edilmesi ve yardıma muhtaç olanın korunması gibi normların inşasında önemli fonksiyonları içermektedir (Duman ve Alacahan, 2011). Bu sermaye türünde kapalı ağ özelliği taşıyan, ayrıcalıklı ya da seçilmiş bireylerin sahip olduğu, ağ yoğunluğun fazla, ilişkilerin sıkı, güçlü ve içe dönük bağların hâkim olduğu homojen bir yapının varlığı esastır (Alan, 2017). Öte yandan, birbirinden farklı ağ ilişkileri elde etmeyi köprüleyici sosyal sermaye olarak ifade eden Putnam (2000), bu sermaye türünde güçlü ve sıkı ilişkilerin varlığından ziyade arada herhangi bir bağlantının varlığının yeterli olacağını belirtmiş̧ir. Farklı etnik, mesleki, sosyo-ekonomik geçmişse 
sahip gruplar arasındaki biçimsel ve biçimsel olmayan ilişkileri kapsayan köprüleyici sosyal sermaye, heterojen grup ilişkilerinde gözlenen güçsüz bağlardan oluşmaktadır (Duman ve Alacahan, 2011). Köprüleyici sosyal sermaye açık ağ özelliği taşımakta ve dişa dönük bağlara sahip, heterojen grupların sahip olduğu, güven ilişkilerinin fazla ve ağ yoğunluğunun az olduğu sosyal sermaye türüdür (Alan, 2017). Bağlayıcı sosyal sermayenin seçkin kimlikleri destekleme ve homojenliği sürdürme eğiliminde olan bir çeşit dışsallaştırıcı sermaye iken; köprüleyici sermayenin ise çeşitli sosyal bölümler içinden insanları bir araya getirme ve heterojenliği sürdürme eğiliminde olan bir tür içselleştireci sermaye olduğunu ifade eden Putnam, bağlayıcı sosyal sermayenin geçinmek için, köprüleyici sosyal sermayenin ise başarılı olmak için önemli olduğunu söylemektedir (Şan ve Şimşek, 2011).

Sosyal sermaye olgusunun bir dinamiği olarak üniversiteler, bireyin eğitim ve öğrenim hayatında önemli bir yere sahiptir. Üniversiteler, sosyal sermayenin temelini oluşturan "etkileşim" olgusunun en çok ve en etkili meydana geldiği kurumlardır. Toprak ve Bozgeyikli'ye (2011) göre üniversiteler öğrencilerin sosyal bir düzlemde bir araya gelmelerine olanak sağlayan üniversiteler, doğrudan veya dolaylı bir biçimde motivasyon ve çabayı etkilemekte ve böylelikle öğrencilerden istenen ya da beklenen değişim hareketinin ortaya çıkmasına yardımcı olmaktadır. Üniversiteler sunmuş oldukları nitelikli eğitsel bölümlerle aracılı̆̆ıyla öğrencileri ileri düzeyde uzmanlık gerektiren bilgi ve becerileri öğrenmeye teşvik ederler. Böylelikle öğrenciler kabiliyetlerini geliştirerek üniversitenin kendilerine sunmuş olduğu ders, derece veya sertifikaları elde edecek yetkinliğe ulaşırlar (Etcheverry, 1996: 48). Dolayısıyla üniversitelerin öğrencilerin kariyer gelişimleri noktasında birçok ihtiyaçlarını karşıladığı ve onlara değer kattığı kurumlar olduğunu söyleyebiliriz. Aynı zamanda üniversiteler, insanlar arasındaki bağlantıyı ve etkileşimi dinamik tutması bakımından da sosyal sermayenin yoğun olarak üretildiği bilim yuvalarıdır (Iş̧1k vd., 2019). Diğer taraftan, bireyler öz yeterliliğini keşfettiğinde katılım gösterdikleri etkileşimlerden (ağlardan) soysal sermaye kazanırlar. Bireyin sosyal sermayeyi köprülemesi (kazanmasında) öz yeterliliğini de etkilemektedir (Wu vd., 2012). Bu doğrultuda aşağıda belirtilen hipotezler geliştirilmiştir.

\section{$\boldsymbol{H}_{1}$ : Köprüleyici sosyal sermayenin girişimcilik niyeti üzerinde etkisi vardır}

$\boldsymbol{H}_{2}$ : Köprüleyici sosyal sermayenin öz yeterlilik üzerinde etkisi vardır

\section{Öz Yeterlilik}

Bandura (1986) bireylerin düşünceleri, duyguları ve eylemleri üzerinde bir kontrol ölçüsü kullanmalarını sağlayan bir öz sisteme sahip olduklarını belirtmiş ve bu öz sistemin, kişinin bilişsel ve duyuşsal yapılarına ev sahipliği yaptığını, sembolize etme, başkalarından öğrenme, alternatif stratejiler planlama, davranış düzenleme, kendini yansıtma ve dahil olma yeteneklerini içerdiğini ifade etmiştir. Ayrıca, Bandura'ya göre öz-sistem ve dış-çevresel etki kaynakları arasındaki etkileşimin sonucu olan referans mekanizmalarının sağlanmasında ve davranış algılayışında, düzenlenmesinde ve değerlendirilmesinde bir takım alt fonksiyonlarda önemli bir rol oynadığını da belirtmiştir. $\mathrm{Bu}$ nedenle, öz sistem, bireye ortamını değiştirme ve kendi eylemlerini etkileme yeteneğini sağlayarak öz düzenleme işlevine hizmet eder. Nihayetinde Bandura, insanların kendileri hakkında sahip oldukları inançların, kontrol ve kişisel yön tayin etme noktasında kilit unsurlar olduğunu belirtmiştir (Pajares, 1996). Bu bağlamda karşımıza yine Bandura tarafindan ortaya atılan öz yeterlilik kavramı çıkmaktadır. Öz yeterlik, bireyin hayatatını etkileyen olaylar üzerinde tesir oluşturan belirlenmiş performans seviyeleri üretme yetenekleri hakkındaki inançları olarak tanımlanmaktadır. Öz yeterlik inancı, bireylerin düşünme, motivasyon ve davranışlarını şekillendirerek kendilerini nasıl hissettiğini belirler (Bandura, 1994). Luszczynska ve arkadaşlarına (2005) göre öz yeterlilik, bireyin zor ve belirsiz görevleri yapabilme ve özel gereksinim gerektiren durumların üstesinden gelebilmek için kendi yetkinliklerine duyduğu inançtır.

Öz yeterlik teorisi, insanların performans başarılarından, başkası için yapılan (gözlemsel) deneyimlerden, ikna etme biçimlerinden ve fizyolojik etkinliği değerlendirmek için bilgi edindiğini 
ileri sürer. Bireyin kendi performansları, etkinliği değerlendirmek için en güvenilir rehberleri sunar. Başarılar etkinliği arttırır ve başarısızlık bunu azaltır, ancak güçlü bir etkinlik duygusu geliştirildiğinde, başarısızlığın çok fazla etkisi olmayabilir (Bandura, 1986). Bandura (1977), öz yeterliliğin bireyin faaliyetlerini, çabalarını ve sebat etme tercihini etkilediğini varsaymıştır. Bir görevi yerine getirme konusunda düşük bir etkinlik hissine sahip kişiler bundan kaçınabilir; yetenekli olduklarına inananlar kolayca katılırlar. Etkili olduklarını hisseden bireyler, yeteneklerinden şüphe edenlere göre zorluklarla karşılaştıklarında daha fazla çalışma ve daha uzun süre devam ettikleri varsayılır. Kişilerin öz yeterlilikleri ne kadar güçlü olursa üstesinden gelebilecekleri olaylar da bir o kadar çok olur (Bakan vd., 2017). Bu bakımdan bireylerin öz yeterlilikleri, yani yeterlilik beklentilerine ilişkin algılamaları, onların harekete geçmelerini ve sorunların üstesinden gelme motivasyonlarını etkilemektedir (Basım vd., 2008).

Bu teoriye göre, iki tür beklenti davranış üzerinde güçlü etkiye sahiptir: sonuç beklentileri; belirli davranışların belirli sonuçlara yol açacağı inancı, ve öz-yeterlilik beklentisi; bir kişinin söz konusu davranışı başarıyla gerçekleştirebileceği inancıdır (Maddux vd., 1982). Bandura'ya (1977) göre, öz yeterlilik beklentileri, davranış değiş̧ikliğinin en güçlü belirleyicileridir; çünkü öz yeterlilik beklentileri bir davranış için, harcanan çaba ve çekilen sıkıntı karşısında yapılan ısrarın kararları belirlediğini ifade etmektedir. Yüksek öz yeterlik, gerekli becerilerin eksik olduğu durumlarda yetkin performans göstermez. Sonuç beklentileri veya eylemlerin olası sonuçlarına ilişkin inançlar önemlidir, çünkü bireyler olumsuz sonuçlara yol açacağına inandıkları şekillerde hareket etme konusunda motive olmazlar. Sonuçların algılanan değeri, insanların başkalarına göre belirli sonuçları ne kadar arzulamak istediklerini ifade eder. Yeterli beceriler, olumlu sonuç beklentileri ve kişisel olarak değerli sonuçlar göz önüne alındığında, çok sayıda insan davranışının seçimini ve yönünü etkilemek için öz yeterli oldukları varsayılır (Schunk, 1991).

Türkçe literatürde öz yeterlilik kavramının farklı disiplinlerde çeşitli değişkenlerle ilişkisinin test edildiği birçok araştırma görülmektedir. Bu araştırmalar ve konu edindikleri ilgili değişkenlerinden bazıları şu şekildedir: iş tatmini (Gençtürk ve Memiş, 2010; Meydan, 2011), tükenmişlik (Arslan, 2019; Çimen, 2007), lider üye etkileşimi (Bolat, 2011), psikolojik güçlendirme (İşcan ve Çakır, 2016) ve örgütsel muhalefet (Bakan vd., 2017), yenilikçilik (Basım vd., 2008), iç girişimcilik (Çetin, 2011; Meydan, 2011), girişimcilik (Çolakoğlu ve Çolakoğlu, 2016; Tokat, 2007). Gerek burada belirtilen araştırmalar gerekse kavramsal ve ampirik bulgular öz yeterliliğin girişimciliği etkilediğini ortaya koymuştur. Buradan hareketle aşağıdaki hipotez geliştirilmiştir;

\section{$\boldsymbol{H}_{3}: \ddot{O}_{z}$ yeterliliğin girişimcilik niyeti üzerinde etkisi vardır}

Alanyazında öz yeterlilik kavramının gerek sosyal sermaye ve gerekse de girişimcilik ile ayrı ayrı ilişkisini ele alan araştırmalar olduğu görülmektedir. Sequeira vd., (2007) yapmış oldukları araştırma sonucunda bireyin öz yeterlilik ile birlikte destekleyici güçlü ağları kurmasının girişimcilik niyetini ortaya çıkardığını tespit etmişlerdir. Han vd., (2014) sosyal sermayenin öz yeterliliği etkilediğini, sosyal ekonomik statünün bu ilişkide aracı bir etkiye sahip olduğunu belirtmiştir. Wu vd., (2012) öz yeterlilik ile sosyal sermaye arasındaki ilişkide sosyal güvenin aracılık ettiğini, bireyin sosyal öz yeterliliğinin sosyal güvenlerini ve böylece sosyal sermayelerini etkilediğini tespit etmiştir. Buradan hareketle öz yeterliliğin arac1 bir etkiye sahip olabileceği düşünülmüş ve aşağıdaki hipotez geliştirmiştir; sahiptir

$\boldsymbol{H}_{5}: \ddot{O}_{z}$ yeterlilik, köprüleyici sosyal sermaye ile girişimcilik niyeti arasinda aracı etkiye

\section{Öz Saygı}

Örgütsel düzlemde araştırma konuları seçilirken göz önünde bulundurulması gereken detaylardan birisi de bireysel farklılıklardır. Bireyler, örgütsel ortamda gerçekleşen olaylara bireysel farklılıklardan dolayı farklı biçimde tepkiler verebilmektedir. Bu bağlamda karşımıza 
bireylerin çevreleriyle etkileşiminde önemli bir faktör olan öz saygı kavramı çıkmaktadır (Güney vd., 2007). Kavrama ilişkin literatür incelendiğinde öz saygının (benlik saygısı) farklı terimlerle yer edindiği; "self-esteem", klasik yayınlarda, "self-respect", "self-confidence", "self-regard" karşıllı̆ı olarak kullanıldığı görülmektedir. Bu terimler Türkçe'de benlik saygısı, öz saygı, kendilik saygısı ve öz değerlilik duygusu olarak ifade edilmekte ve bunlarla eş anlam taşımaktadır (Bektaş ve Kenar, 2017; Dilmaç ve Ekşi, 2008). Bir bireyin kendisine yönelik yapmış olduğu derinlemesine bir değerlendirme olan öz sayg1 (Ayan, 2019; Yüner, 2018), bireyin duygularına dayalı olarak kendisini olumlu veya olumsuz şeklinde tanımlamasıdır. Daha açıkça ifade etmek gerekirse öz sayg1, kişinin bir birey olarak kendisine ilişkin kişisel bir değerlendirme ve kendisini ne düzeyde yetenekli bulduğuna yönelik inanç düzeyini gösteren bir kavramdır (Coopersmith, 1967). Dolayısıyla öz sayg1, bireyin kendisine dair temel bir değerlendirme olup, kendisine inanmas1, güven ve saygı duyması şeklinde ifade edilebilecek duygu, düşünce ve davranışlarından oluşmaktadır (Harter, 1990; Koç, 2009).

Bireylerin sosyal yaşamlarını etkileyen öz saygı, literatürde düşük ve yüksek öz saygı şeklinde ifade edilmektedir. Kendisini olumlu değerlendiren ve iyi hisseden bireyler yüksek öz saygıll, sıkılgan ve öz güvenleri düşük olan bireyler ise düşük öz saygılı kimseler olarak tanımlanmaktadır (Reisoğlu vd., 2013). Düşük öz saygılı bireyler, daha çok kabul gördükleri, onaylandıkları sosyal ortamları tercih ederler. $\mathrm{Bu}$ kişiler onaylanmadıkları ya da onay beklentilerinin giderilmediği ortamlardan kaçınırlar. Bu bakımdan düşük öz saygıya sahip olan bireyler mutsuz, endişe, korku ve utanma gibi duygulanımlar ile olumsuz davranışlar sergilemektedirler. Ancak, bu durumun bütünüyle kötü olarak değerlendirilmemesi gerektiği, aksine bu durumların bazı bireylerde olumsuzluklar ile baş etme duygusunu geliştirdiği iddia edilmektedir (Jones, 1973'Akt. Lena Taş̧̧lar ve Kanl, 2014). Öte yandan, yüksek öz saygı bireyin kendisini yeterince iyi hissetmesi olarak ifade edilmektedir (Rosenthal vd., 2019). Yüksek öz sayg1 inancı hisseden bireyler pozitif davranış ve tutum sergileyen ve bu yönde davranışlarını geliştiren ve devam ettiren kişilerdir. Bu kişiler, örgütsel hedeflere hizmet etme ve gerçekleştirme de ekin olduklarını bilirler. Dolayısıyla bu kişiler daha üretken olmakla birlikte, işlerinden duydukları tatmin de daha yüksek olmaktadır (Yüner, 2018). Araştırmalara göre; öz saygısı yüksek bireylerin diğer bireylerle karşılaştırıldıklarında daha mutlu, yaratıcı, üretken ve başarılı olmaya eğilim gösterdikleri, karşılaştıkları zorluklarla başa çıkma konusunda daha dirayetli ve istekli olduklarını, öz saygısı düşük olan bireylerin ise kaygılı, geleceğe endişe ile bakan, karşılattıkları zorlukların üstesinden gelmek için çaba göstermekten imtina ettiklerini ortaya koymuştur (Mehrotra ve Chaddha, 2013' Akt. Mert ve Şen, 2019). Ayrıca, düşük özsaygı düzeyine sahip bireylerin yalnızlık psikolojisi içerinde olabildiklerini ve bir takım sağlık sorunları ile karşılaşabildikleri de (Reisoğlu vd., 2013) ortaya konulmuştur.

Öz sayg1 (kendine sayg1, benlik saygısı) kavramının Türkçe alan yazında birçok araştırmaya konu olduğu görülmektedir. Leana-Taşcılar ve Kanlı (2014) tarafindan mükemmeliyetçilik ve öz-saygı arasındaki ilişkiyi incelemiş ve araştırma sonucunda öz saygının yüksek olmasının mükemmeliyetçiliğe ket vurduğunu ortaya koymuştur. Arseven (2016) yapmış olduğu kavramsal araştırmada; öz saygı ile öz yeterlilik ve öz güven arasında yakın ilişkiler olduğunu, öz yeterliliğin öz saygının eyleme özgü bir versiyonu olarak düşünüldüğünü belirtmiştir. Duygusal emek, öz saygı ve yaşam tatmini ilişkisini inceleyen Akyüz (2018), araştırmasının sonucunda; öz-saygı düzeyinin yaşam tatmin düzeyini pozitif yönde etkilediğini, bunun yanında öz-saygı düzeyi arttıkça yaşam tatmin düzeyinin de arttığını tespit etmiştir. Bektaş ve Kenar (2017) kendine saygi değişkenini üniversite öğrencilerinin sosyal uyumlarıyla olan ilişkisi çerçevesinde ele almış, araştırma sonucunda; üniversite öğrencilerinin kendine saygı düzeyleri arttıkça sosyal açıdan çevrelerine daha fazla uyum sağladıklarını bulgulamıştır. Alparslan vd., (2019) girişimcilik niyeti ve kültür ilişkisini ele aldığı araştırmasında, öz saygının artmasının bireyin girişimcilik niyetini de arttırdığını ortaya koymuştur. Bu bağlamda aşağıdaki hipotez geliştirilmiştir;

$\boldsymbol{H}_{4}$ : Öz saygının girişimcilik niyeti üzerinde etkisi vardır 
Yapılan araştırmalar öz yeterlilik, öz saygı ve girişimciliğin birbirini etkileyen ve birbirinden beslenen kavramlar olduğunu göstermektedir. Dündar ve Ağca (2007), bir girişimcinin kendisine sayg1 duyduğu ve yeteneklerine güvendiği takdirde başarılı olabileceğine yönelik inancının artacağını ifade etmiştir. Yani bireyin öz saygısının yüksek olmasının girişimcilik niyetine olumlu etki ettiğini söylemek mümkündür. Literatürde, öz yeterlilik ve girişimcilik arasındaki ilişki ile birlikte, öz yeterliliğin girişimciliğe etki eden bir değişken olduğunu ortaya koyan birçok araştırma (Çolakoğlu ve Çolakoğlu, 2016; Çetin, 2011; Meydan, 2011; Tokat, 2007) mevcuttur. Ayrıca öz saygının hem girişimcilik niyeti (Collins ve Moore, 1964; Alparslan vd., 2019) hem de öz yeterlilik (Gardner ve Pierce, 1998; Kunz ve Kalil, 1999) ile yakından ilişkili olduğunu göstermektedir. Bu bakımdan aşağıdaki hipotez geliştirilmiştir; sahiptir

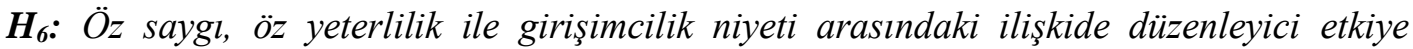

\section{Yöntem}

$\mathrm{Bu}$ çalışmada planlı davranış teorisi perspektifinden, üniversitenin öğrencilere sunduğu sosyal sermayenin öğrencilerin girişimci olma niyetleri üzerindeki etkisi ve bu iki değişken arasındaki ilişkide öz yeterliliğin aracı rolünün ortaya konulması amaçlanmıştır. Ayrıca öz yeterlilik ile girişimcilik niyeti arasındaki ilişkide öz saygının düzenleyicilik etkisinin tespit edilmesi amaçlanmıştır. Düzenleyici aracılı bu modelin test edilmesi için nicel araştırma yöntemlerinden olan anket tekniği ile Doğu Anadolu Bölgesi'nde yer alan üniversitelerde öğrenim görmekte olan işletme bölümü öğrencilerinden veri toplanmıştır. Elde edilen veriler yapısal eşitlik modellemesi yaklaşımına göre MPlus 8.3 ve SPSS 25 programları aracılı̆̆ııla test edilmiştir. Iacobucci, Saldanha ve Deng (2007), YEM'in teorik ve ampirik çalışmaların istatistiki olarak daha gelişmiş bir zeminde yapılmasını sağladığını belirtmiştir. Ayrıca YEM yaklaşımlarının tutarlı bir şekilde bir aracılık rolü sonucunu tespit etmede, regresyon yaklaşımından daha güçlü olacağını deneysel olarak kanıtlamıştır. Bu nedenlerle araştırmanın analiz yöntemi olarak YEM tercih edilmiştir. Araştırmanın modeli Şekil 1'deki gibidir.

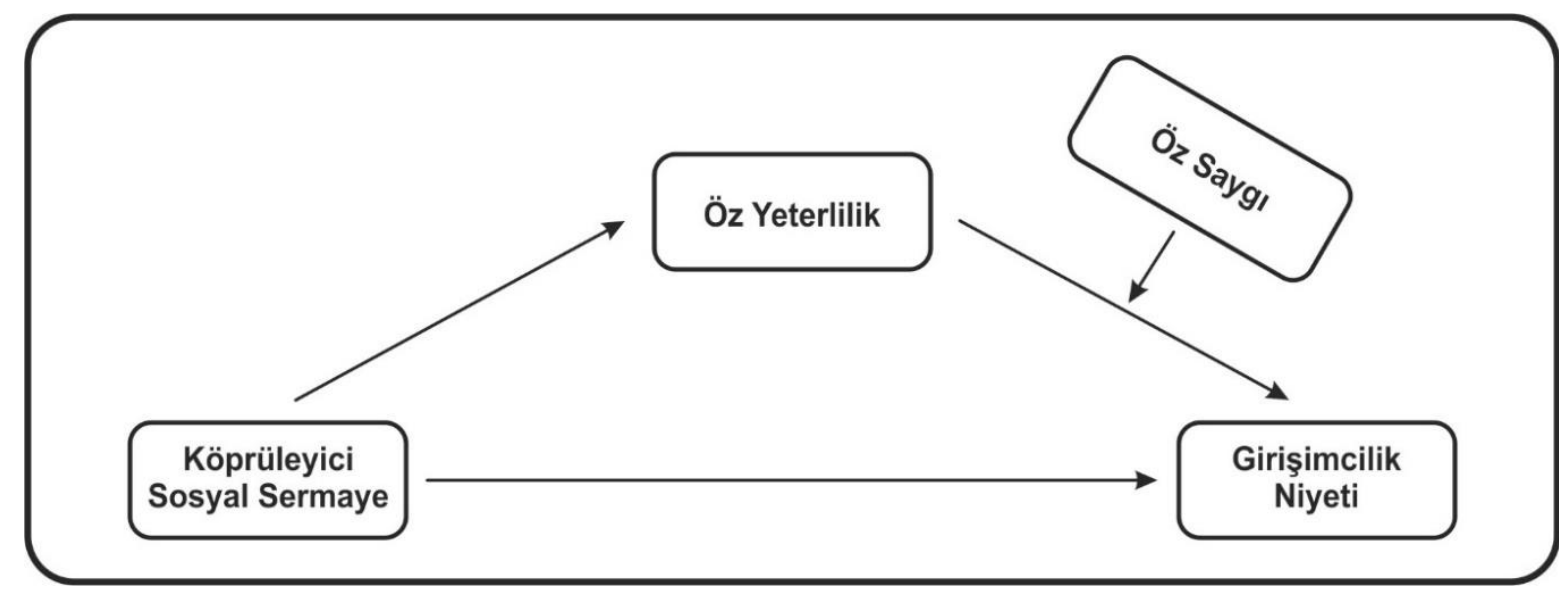

Şekil 1. Araştırmanın Modeli

\section{Katılımcılar ve Ölçüm Araçları}

Araştırmanın anakütlesini Doğu Anadolu Bölgesi'nde yer alan üniversitelerin işletme bölümü öğrencileri oluşturmaktadır. Yükseköğretim Kurulu (YÖK) verilerine göre bölgedeki 17 üniversitede yaklaşık 11.000 işletme öğrencisi bulunmaktadır. Bu öğrencilerin tümüne ulaşmak mümkün olmayacağından örnekleme yapılmıştır. Örnekleme yöntemi olarak tesadüfi olmayan örnekleme yöntemlerinden kolayda örnekleme yöntemi kullanılmıştır. Örneklemi hesaplamak için hassasiyet temelli yaklaşım kullanılmıştır. Buna göre örneklem aşağıdaki formüle göre Excel 2019 programı ile hesaplanmıştır. 


$$
\mathrm{n}=\mathrm{N} * \frac{\frac{Z^{2} * \mathrm{p} *(1-\mathrm{p})}{e^{2}}}{\left[N-1+\frac{Z^{2} * p *(1-p)}{e^{2}}\right]}
$$

Formülde $\mathrm{N}$ popülasyonu, $\mathrm{Z}$ istenilen güven seviyesinde normal dağılımın kritik değerini, $\mathrm{p}$ örneklem oranını, e ise hata payını göstermektedir. SPSS programı aracilığıyla elde edilen bu değerlere ve $\% 5$ hata payına göre yapılan hesaplama sonucunda örneklem büyüklüğü $n=511$ olarak hesaplanmıştır. Ankete toplam 611 öğrenci katılmıştır. Fakat 7 anket çoğu ifade cevaplandırılmadığı için değerlendirmeye alınmamıştır. Böylece toplam 604 anket değerlendirilmeye alınmıştır. Örneklem büyüklüğü hassasiyet temelli yaklaşıma göre hesaplandığından bu sayısının anakütleyi temsil ettiği varsayılmıştır.

Veri toplamak için oluşturulan anket formu çalışmanın niteliğini, gizlilik konularını ve katılımın gönüllü olduğunu belirten bir kapak sayfasının yanı sıra beş bölümden oluşmuştur. İlk bölümde katılımcıların demografik bilgilerini öğrenmeye yönelik sorular yer almıştır. Buna göre katılımcıların \%52'si (n=314) kadın, \%48'i ise (n=290) erkektir. Yaş ortalaması ise 22,41'dir.

İkinci kısımda Steinfield, Ellison ve Lampe (2008) tarafindan geliştirilen ve 8 maddeden oluşan köprüleyici sosyal sermaye ölçeği kullanılmıştır. Ölçek üniversitelerde uygulandığından, tam amaca hizmet ettiği düşünüldüğg̈ için diğer alternatiflerine tercih edilmiştir. Örnek ölçek maddeleri: "Üniversitemde olup bitenlerle ilgilenirim" ve "Üniversitemdeki bireylerle etkileşim kurmak beni daha büyük bir topluluğun parçası gibi hissettiriyor".

Üçüncü kısımda Steinfield, Ellison ve Lampe'nin (2008) köprüleyici sosyal sermaye ile aynı çalışmalarında kullandıkları öz saygı ölçeği kullanılmıştır. 7 maddeden oluşan ölçeğin 3 . ve 5 . maddeleri ters kodlanmıştır. Hazırlanan anket formunda bu sıralamaya sadık kalınmıştır. Ölçeğin tercih edilmesinin temel sebebi köprüleyici sosyal sermaye ile birlikte kullanılması ve üniversitelerde uygulanmış olmasıdır. Örnek ölçek ifadeleri: "Bütün olarak değerlendirildiğinde başarısız hissetmeye meyilliyim (R)" ve "Diğer insanların yaptığ 1 şeyleri ben de yapabilirim".

Anketin dördüncü kısmında Schwarzer, Mueller ve Greenglass (1999) tarafindan geliştirilen öz yeterlilik ölçeği yer almıştır. 10 maddeden oluşan bu ölçek literatürde oldukça sık kullanılan bir ölçektir. Örnek ölçek maddeleri: "Yeterince sıkı çalışırsam zorlukların üstesinden gelebileceğime inanıyorum" ve "Yoluma ne çıkarsa çıksın genellikle baş edebilirim".

Son kısımda Liñán ve Chen (2009) tarafindan geliştirilen ve 6 maddeden oluşan girişimcilik niyeti ölçeği kullanılmıştır. Örnek ölçek ifadeleri: "Girişimci olmak için her şeyi yapmaya hazırım", "Mesleki hedefim girişimci olmak" ve "Bir gün iş yeri sahibi olmaya güçlü bir şekilde niyetliyim".

Tüm ölçekler 5'li likert tipindedir. Ölçek aralıkları "1- Hiç katılmıyorum" ve "5- Tamamen katılıyorum" şeklinde kodlanmıştır.

\section{Ölçüm Modeli}

Elde edilen veriler, Anderson ve Gerbing'in (1988) önerdiği; verileri analiz etme ve hipotezleri test etme adımlarından oluşan, iki aşamalı yapısal eşitlik modellemesi yaklaşımına göre MPlus 8.3 programı ile analiz edilmiştir. Ölçüm modeli oluşturulmadan önce SPSS 25 programı ile veriler taranmıştır. Eksik verilere ortalama değerler atanmıştır ve değişkenlerin çarpıklık ve basıklıkları kontrol edilmiştir. Değerler $+1,5$ ve $-1,5$ sınırını aşmadığı için dağılım normal kabul edilmiştir (Tabachnick, Fidell, \& Ullman, 2007). Daha sonra çoklu bağlantı sorunu olup olmadığına bakılmıştır. Değişkenler arasındaki doğrusal regresyon analizi ile elde edilen VIF değerleri literatürde sıkça kabul gören 5 değerinin oldukça altında olduğu için çoklu bağlantı sorunu olmadığı görülmüştür (Craney ve Surles, 2002; Thompson, Buch ve Glasø, 2017). 
Yapısal eşitlik modeli kurmadan önce ölçüm modelinin yeterli düzeyde geçerlilik ve güvenilirliğe sahip olması gerekmektedir (Fornell ve Larcker, 1981). Bunun için ölçeklerin uyuşum ve ayırt edici geçerliliği sağlaması ve iyi uyum değerlerine sahip olması, ayrıca cronbach's $\alpha$ değerinin kabul edilebilir sınırlar içerisinde olması beklenmektedir. Ölçeklerin uyuşum geçerliliğini sağlaması için tüm faktör yüklerinin 0,50 eşiğinden fazla olması (Fornell ve Larcker, 1981), maddelerde kendi yapılarıyla çıkarılan ortalama varyansın (AVE) açıklanamayan varyanstan (AVE $>0.50$ ) büyük olması (Bagozzi ve $Y i, 1988$ ) ve faktör kompozit güvenilirliğinin (CR) 0,60'a eşit veya daha büyük olması gerekmektedir (Fornell ve Larcker, 1981).

Kurulan ölçüm modelinin iyilik uyum indekslerinin kabul edilebilir sınırlar içerisinde $(\mathrm{Hu} \&$ Bentler, 1999; Sivo, Fan, Witta, \& Willse 2006) olduğu görülmüştür $\chi^{2} / \mathrm{df}=3.542$, RMSEA = 0.065, GFI $=0.968$, AGFI $=0.953$, TLI $=0.923$, CFI $=0.940$. Fornell ve Larcker $(1981)$ AVE ve CR hesaplanması için aşağıdaki formülleri önermiştir.

$$
\begin{gathered}
A V E=\frac{\sum_{i=1}^{n} \lambda^{2}}{\mathrm{n}} \\
C R=\frac{\left(\sum_{i=1}^{i} \lambda_{i}\right)^{2}}{\left(\sum_{i=1}^{i} \lambda_{i}\right)^{2}+\left(\sum_{i=1}^{i} 1-\lambda_{i}^{2}\right)}
\end{gathered}
$$

Yukarıdaki formüllere göre değişkenlerin AVE ve CR değerleri Excel 2019 programı yardımıyla hesaplanmıştır. Ayrıca değişkenler arası korelasyonlara bakılmıştır. AVE değerlerinin hesaplanmasından önce faktör değeri 0.50'nin altında olan sosyal sermaye ölçeğinin 2. maddesi ve öz saygı ölçeğinin 5. maddesi analizlerden çıkarılmıştır. Kalan maddeler üzerinden hesaplanan AVE ve CR değerleri ile korelasyon analizi sonuçları, ölçek ortalamaları, standart sapmaları ve Cronbach $\alpha$ değerleri Tablo 1'de verilmiştir.

Tablo 1. Tanımlayıcı İstatistikler

\begin{tabular}{lcccccccc}
\hline & Ort. & SS. & AVE & CR & $\mathbf{1}$ & $\mathbf{2}$ & $\mathbf{3}$ & $\mathbf{4}$ \\
\hline 1. Sosyal Sermaye & 3,25 &, 920 & 0,524 & 0,765 & $\mathbf{( , 8 4 1 )}$ & & & \\
\hline 2. Girişimcilik Niyeti & 3,51 &, 924 & 0,523 & 0,867 & $0,288^{* * *}$ & $\mathbf{( , 8 6 5 )}$ & & \\
\hline 3. Öz Saygı & 3,91 &, 727 & 0,511 & 0,806 & $0,252^{* * *}$ & $0,355^{* * *}$ & $\mathbf{( , 8 7 6 )}$ & \\
\hline 4. Öz Yeterlilik & 4,11 &, 669 & 0,546 & 0,783 & $0,269 * * *$ & $0,412^{* * *}$ & $0,701 * * *$ & $\mathbf{( , 7 4 7 )}$ \\
\hline
\end{tabular}

$* * * \mathrm{p}<0.001 ; \quad$ Ort=Ortalama; SS=Standart Sapma; AVE $=$ Average Variance Extracted; $\mathrm{CR}=$ Composit Reliability

Tablo 1'de görüleceği üzere AVE değerleri 0.50'den yüksek CR ve parantez içerisinde koyu renkte verilen Cronbach's $\alpha$ değerleri 0.60 'dan yüksek olduğu için ölçeklerin yeterli düzeyde geçerlilik ve güvenilirliği sağladığı sonucuna ulaşılmıştır.

\section{Yapisal Model}

Araștırmada oluşturulan hipotezleri test etmek üzere iki adet yapısal eșitlik modeli kurulmuştur. İlkinde köprüleyici sosyal sermayenin girişimcilik niyeti üzerindeki etkisini ve bu ilişkide öz yeterliliğin aracı rolünü tespit etmeye yönelik kurulmuştur. İkinci modelde ise öz yeterlilik ile girişimcilik niyeti arasındaki ilişkide öz saygının düzenleyici etkisi ortaya konulmak istenmiştir. Kurulan modellerin uyum indeksleri Tablo 2'de verilmiştir.

Tablo 2. Yapısal Modellerin Uyum İndeksleri

\begin{tabular}{lccccccc}
\hline & $\chi^{\mathbf{2} / \mathbf{d f}}$ & AGFI & GFI & CFI & NFI & TLI & \multicolumn{2}{c}{ RMSEA } \\
& $<\mathbf{5}$ & $>\mathbf{. 8 5}$ & $>\mathbf{8 0}$ & $>\mathbf{. 9}$ & $>\mathbf{9 0}$ & $>. \mathbf{9 0}$ & $<.08$ \\
\hline${\text {.. } \text { Model }^{\mathbf{1}}}^{2}$ & 2,142 &, 980 &, 950 &, 975 &, 943 &, 957 &, 072 \\
\hline $\mathbf{2 . ~}$ Model $^{\mathbf{2}}$ & 1,218 &, 991 &, 998 &, 993 &, 981 &, 987 &, 040 \\
\hline
\end{tabular}

\footnotetext{
${ }^{1}$ Aracılık Modeli; ${ }^{2}$ Düzenleyicilik Modeli
} 
Tablo 2'den anlaşılacağ edilebilir sınırlar içerisindedir (Hu \& Bentler, 1999; Sivo, Fan, Witta, \& Willse 2006). İlk modeldeki doğrudan ilişkileri gösteren yol analizi sonuçları Tablo 3'de verilmiştir.

Tablo 3. Doğrudan İlişki Analizi Sonuçları

\begin{tabular}{|c|c|c|c|c|c|c|}
\hline & & & Katsayı ${ }^{1}$ & S.H. & K.O. & $\mathbf{P}$ \\
\hline Girişimcilik Niyeti & $\leftarrow$ & Sosyal Sermaye &, 308 &, 040 & 4,863 & $* * *$ \\
\hline Öz Yeterlilik & $\leftarrow$ & Sosyal Sermaye & 251 & ,042 & 4,452 & $* * *$ \\
\hline Girişimcilik Niyeti & $\leftarrow$ & Öz Yeterlilik &, 416 & ,064 & 7,752 & $* * *$ \\
\hline
\end{tabular}

Modeldeki ilişkiler incelendiğinde, sosyal sermayenin girişimcilik niyeti $(\beta=-, 308$; $\mathrm{p}<0,001)$ ve öz yeterlilik $(\beta=-, 251 ; p<0,001)$ üzerinde pozitif yönlü anlamlı bir etkiye sahip olduğu görülmüştür. Ayrıca öz yeterliliğin girişimcilik niyeti üzerinde $(\beta=-, 416 ; p<0,001)$ pozitif bir etkiye sahip olduğu görülmüş̧ür. Araştırmanın bu sonuçlarına göre " $\boldsymbol{H}_{1}$ : Köprüleyici sosyal sermayenin girişimcilik niyeti üzerinde etkisi vardır, $\boldsymbol{H}_{2}$ : Köprüleyici sosyal sermayenin öz yeterlilik üzerinde etkisi vardır, $\boldsymbol{H}_{3}: \ddot{O}_{z}$ yeterliliğin girişimcilik niyeti üzerinde etkisi vardır" hipotezleri kabul edilmiştir.

Baron ve Kenny (1986) yaptıkları çalışmada aracı değişkeni; bağımsız değişken ile bağımlı değişken arasındaki etkinin üretkenliği şeklinde tanımlamıştır. Ayrıca aracılık etkisini üç koşula bağlamıştır. Buna göre, birinci koşul bağımsız değişkenin bağımlı değişkeni etkilemesi, ikinci koşul bağımsız değişkenin aracı değişkenler üzerinde bir etkisinin olması, üçüncü koşul aracı değişkenin bağımlı değişkeni etkilemesidir. Tüm bu koşulların sağlanması durumunda; aracı etki modele girdiği taktirde bağımlı değişken ile bağımsız değişken arasındaki ilişki azalıyorsa kısmi, bağımlı değişken ile bağımsız değişken arasındaki ilişki anlamsızlaşıyorsa tam aracılığın olduğunu savunmuşlardır. Baron ve Kenny'nin (1986) yaklaşımı bootstrap yöntemiyle analiz edilmiştir. Mallinckrodt vd. (2006) çalışmalarında deneysel araştırmalarda bootstrap analizlerinin kitle parametresine ilişkin güven aralığının hesaplanmasının faydalı olduğunu belirtmişlerdir. Bootstrap örneklemi ise 5000 olarak belirlenmiştir. Aracı değişken analizi sonuçları Tablo 4'de verilmiştir.

Tablo 5. Dolaylı İlişki Analizi Sonuçları

\begin{tabular}{|c|c|c|c|c|}
\hline Hipotez & $\begin{array}{c}\text { Doğrudan } \\
\text { Etki }^{1} \\
\beta\end{array}$ & $\begin{array}{c}\text { Doğrudan } \\
\text { Etki }^{2} \\
\beta\end{array}$ & $\begin{array}{c}\text { Dolaylı Etki } \\
\beta\end{array}$ & Aracilık Durumu \\
\hline $\begin{array}{l}\text { H}_{5}: \text { Sosyal Sermaye } \rightarrow \text { Öz Yeterlilik } \rightarrow \\
\text { Girişimcilik Niyeti }\end{array}$ &, $308 * * *$ &, $104(\mathrm{~ns})^{3}$ &, $104 * *$ & Tam Aracılık \\
\hline
\end{tabular}

Model 1'deki aracılık etkisini ortaya koymak üzere yapılan analizin sonuçlarına göre aracı değişken eklenmeden önce sosyal sermaye ile girişimcilik niyeti arasında $(\beta=, 308 ; p<0.001)$ pozitif yönlü anlamlı bir ilişki vardır. Modele öz yeterlilik değişkeni aracı olarak eklendiğinde bu ilişki $(\beta=, 104 ; p>0.05)$ azalarak anlamsızlaşmıştır. Ayrıca bootstrap yöntemiyle test edilen modelde öz yeterlilik eklendiğinde modelin anlamlı bir dolaylı etkiye sahip olduğu da $(\beta=, 104 ; p<0.001)$ görülmüştür. $\mathrm{Bu}$ durumda " $\boldsymbol{H}_{5}:$ Öz yeterlilik, köprüleyici sosyal sermaye ile girişimcilik niyeti arasında aracı etkiye sahiptir” hipotezi kabul edilmiştir.

Baron ve Kenny (1986) düzenleyici değişkeni; bağımsız ve bağımlı değişken arasındaki ilişkinin etki gücünü ve yönünü etkileyen bir değişken olarak tanımlamıştır. Bu çalışmada öz yeterlilik ile girişimcilik niyeti arasındaki ilişkide öz saygının düzenleyici etkiye sahip olduğu öngörülmüş̧ür. Bu bağlamda oluşturulan modelin yol analizi sonuçları Tablo 6'da verilmiştir. 
Tablo 6. Düzenleyici Etki Analizi Sonuçları

\begin{tabular}{lllcccc}
\hline & & & Katsayı $^{\mathbf{1}}$ & S.H. & K.O. & P \\
\hline ZGirişimcilik Niyeti & $\leftarrow$ & ZÖzYeterlilik &, 538 &, 133 & 4,049 & $* * *$ \\
\hline ZGirişimcilik Niyeti & $\leftarrow$ & ZÖzSayg1 &, 160 &, 172 &, 927 &, 008 \\
\hline ZGirişimcilik Niyeti & $\leftarrow$ & ZÖzYeterlilkXÖzSayg1 &, 266 &, 264 & 1,006 &, 004 \\
\hline 'Standadize edilmiş katsayılar verilmiştir; ${ }^{* * *} \mathbf{p}<\mathbf{0 . 0 0 1}$; S.H.=Standart Hata; K.O.=Kritik Oran & &
\end{tabular}

Kurulan ikinci modelin yol analizi yapılmadan önce SPSS 25 programında etkileşim terimi oluşturulmuştur (özyeterlilikXözsaygı). Daha sonra değişkenlerin merkezlenmiş ortalaması (mean centered - zcore) alınmıştır. Bu değişkenler ile yapılan yol analizi sonucuna göre öz yeterlilik $(\beta=, 538 ; p<0.001)$ ve öz saygının $(\beta=, 160 ; p<0.01)$ girişimcilik niyeti üzerinde pozitif yönlü anlamlı bir etkiye sahip olduğu görülmüş̧ür. Bu sonuçlara göre " $\boldsymbol{H}_{4}$ : $\ddot{O}_{z}$ saygının girişimcilik niyeti üzerinde etkisi vardır" hipotezi kabul edilmiştir. Ayrıca etkileşim teriminin (özyeterlilikXözsaygı) de girişimcilik niyeti üzerinde $(\beta=, 266 ; p<0.01)$ pozitif yönlü ve anlamlı bir ilişkiye sahip olduğu görülmüştür. İlişkinin yönüyle ilgili daha detaylı inceleme yapmak için Cohen vd., (2014) tarafından önerilen süreç izlenmiştir. Bu doğrultuda, değişkenler arasındaki ilişkinin anlamlılığını ayrıntılı bir şekilde görebilmek için regresyon eğrisi çizilmiş ve Aiken, West ve Reno (1991) tarafından önerilen Slope test analiz yöntemi uygulanmıştır. Çizilen regresyon eğrisi Şekil 2'de verilmiştir.

Şekil 2. Düzenleyici Etki Analizi Slope Matrisi

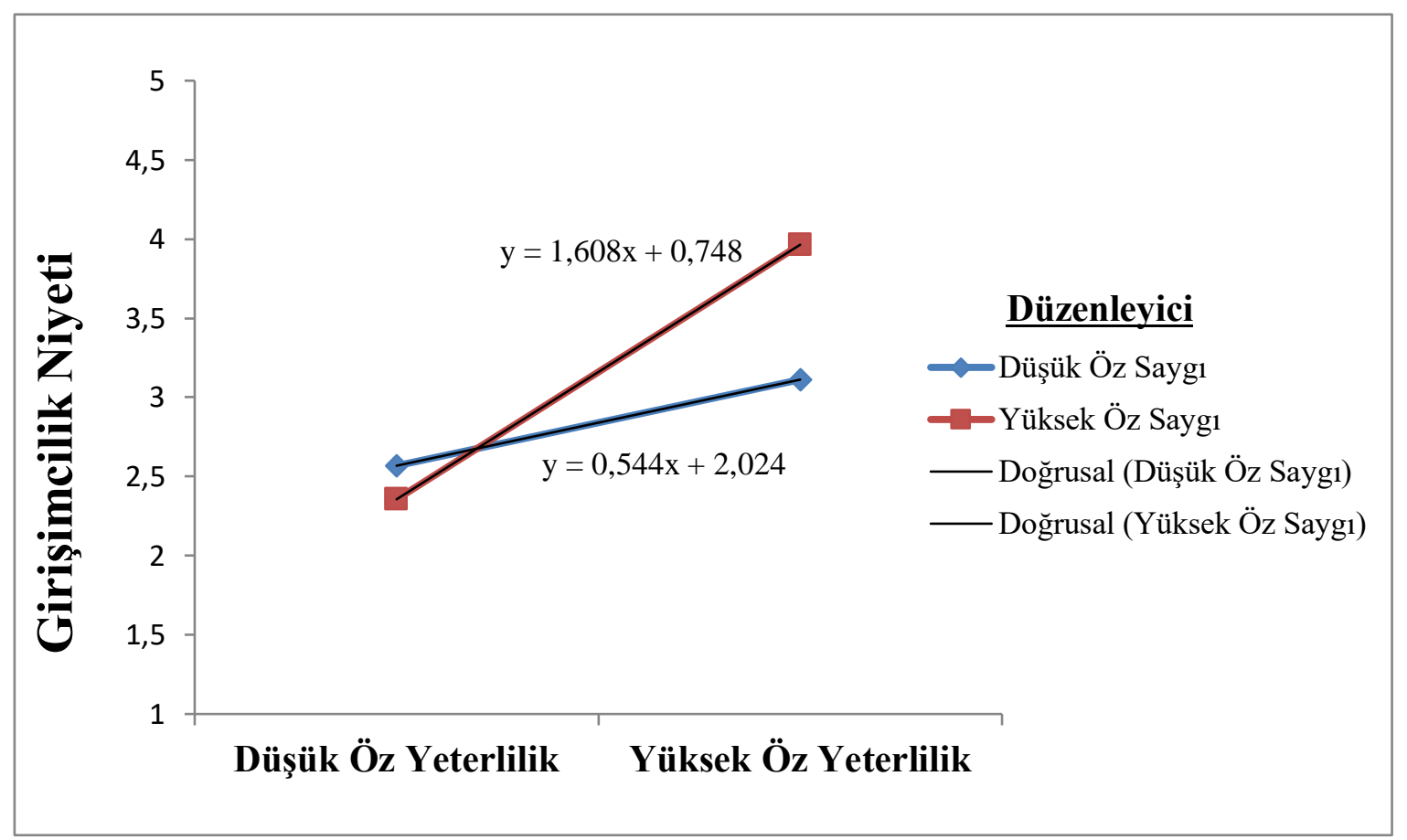

Şekilde görüldüğü üzere, doğruların paralel olmaması düzenleyici etkinin varlığını kanıtlamaktadır. Öz saygının arttığı durumlarda girişimcilik niyetinin arttığı da görülmektedir. Buna göre öz saygının, öz yeterlilik ile girişimcilik niyeti arasındaki pozitif ilişkiyi güçlendirdiği sonucuna ulaşılmıştır. Çalışmanın bu bulgusuna göre " $\boldsymbol{H}_{6}: \ddot{O} z$ saygl, öz yeterlilik ile girişimcilik niyeti arasındaki iliş̧kide düzenleyici etkiye sahiptir" hipotezi desteklenmiştir. 


\section{Sonuç ve Tartışma}

$\mathrm{Bu}$ araştırmada sosyal sermaye, öz yeterlilik ve öz saygının girişimcilik niyeti üzerindeki rolü incelenmiştir. Araştırma kapsamındaki değişkenlerin kuramsal yapısı itibariyle üniversite öğrencileri üzerinde en iyi şekilde uygulanabileceği ve test edilebileceği düşünülmüss, bu bakımından araştırma üniversite öğrencileri üzerinde gerçekleştirilmiştir. Üniversiteler, öğrencilerin sosyal bir düzlemde bir araya gelmelerine olanak sağlamakta, doğrudan veya dolaylı bir biçimde motivasyon ve çabalarını etkilemekte ve böylelikle onlardan istenen veya beklenen değişim hareketinin ortaya çıkmasına yardımcı olmaktadır. Ayrıca, üniversiteler öğrencilere kendilerini gerçekleştirmeleri için değişimler sağlaması ve sosyal sermaye yönünden uygun imkanlar sunması bakımından etki düzeyi yüksek bir öğrenme kurumu niteliğindedirler (Toprak ve Bozgeyikli, 2011). Üniversiteler, birçok eğitim ve öğretim metoduyla (ders, kurs, uygulamalar veya sertifikalar) öğrencilerin kabiliyetlerini geliştirerek yetkinliğe ulaşmalarına olanak sunmaktadır (Etcheverry, 1996: 48). Öğrencilerin kariyer gelişimleri noktasında birçok ihtiyaçlarını karşılayan ve onlara değer katan üniversiteler, bireyler arasındaki bağlantıyı ve etkileşimi dinamik tutması bakımından da sosyal sermayenin yoğun olarak üretildiği yerlerdir. Bu anlamda üniversitelerin sosyal sermayenin kazanılması noktasında öğrencilere imkanlar sunması öğrencilerin kendilerine olan inancını artırmaktadır (Işık vd., 2019). Dolayısıyla, üniversitelerin yüksek öz saygı hisseden, öz yeterli olduğuna inanan ve en nihayetinde girişimci bir kişiliğe sahip bireylerin yetişmesine zemin hazırlayan önemli birer eğitim ve öğrenim kurumları olduğunu söyleyebiliriz.

Araştırma sonucunda sosyal sermayenin girişimcilik niyeti üzerinde pozitif yönlü anlamlı bir etkiye sahip olduğu görülmüş̧ür. Nitekim sosyal sermayenin girişimcilik üzerinde etkili olduğu birçok araştırmada ortaya konulmuştur (Bknz. Yetim, 2002; Özdevecioğlu ve Cingöz, 2009; Akyazı, 2014; Aşkın ve Barış, 2016). Üniversitelerin, güçlü birer sosyal yapılar olduğu düşünüldüğünde bu etki aslında beklenilen bir durumdur. Üniversiteler öğrencilere sadece bilgi aktarmanın ötesinde, onlara belki de tüm hayatları boyunca kullanabilecekleri bir sosyal sermaye sunmaktadır. Bu sayede öğrenciler gerek sosyal yaşamlarında gerekse de iş yaşantılarında bu sermayeyi kullanabilmektedir (Işık vd., 2019).

Yapılan analizlerde sosyal sermayenin öz yeterlilik üzerinde de pozitif yönlü anlamlı bir etkiye sahip olduğu tespit edilmiştir. Bu sonuç, Steinfield vd., (2008) ve Burke vd., (2011) araştırmaları ile desteklenmektedir. Diğer taraftan, araştırmada öz yeterliliğin girişimcilik niyeti üzerinde pozitif bir etkiye sahip olduğu sonucuna varılmıştır. Bu durum literatürde öz yeterlilik ve girişimcilik ilişkisini konu edinen ve öz yeterliliğin girişimciliği etkilediğini ortaya koyan araştırmalarca (Çolakoğlu ve Çolakoğlu, 2016; Tokat, 2007; Çetin, 2011; Meydan, 2011) desteklendiğine işaret etmektedir.

Araştırmada bir diğer sonuç olarak öz saygının girişimcilik niyetini etkilediği tespit edilmiştir. Bu sonucun Alparslan ve arkadaşlarının (2019) araştırma sonuçları ile desteklendiği görülmüş̧ür. Nitekim Dündar ve Ağca (2007), bir girişimcinin kendisine saygı duyduğu ve yeteneklerine güvendiği takdirde başarılı olabileceğine yönelik inancının artacağını ifade etmiştir. Buradan hareketle, bir bireyin öz saygısının yüksek olmasının onun girişimcilik niyetine olumlu etki ettiğini söyleyebiliriz. Ancak, Shane'ye (2007) göre öz sayg1, girişimcide, zamanla ve kurmuş olduğu işinde başarıya ulaşma serüveninde karşılaştı̆̆ 1 zorlukların üstesinden gelme mücadelesi verirken oluşturmaktadır. Arslan ve Yener'e (2015) göre bu durum, girişimcinin yaşadığ 1 deneyimlerle birlikte, bir şeyler öğrenmesinin zaman içerisinde onda saygı duygusunun oluşmasına zemin hazırlamaktadır. Kanaatimizce, yüksek öz saygı varlığının girişimciliğe etki ettiğini belirten birinci görüş ile girişimcinin başardıkça öz saygısının da artığını ifade eden ikinci görüş de yerinde birer değerlendirmedir.

Öz saygının girişimcilik niyeti üzerindeki etkisi araştırmada sınanan bir diğer hipotezdir. Arora ve diğerleri de (2013) öz sayg1, öz yeterlilik ve girişimcilik niyetinin birbiriyle ilişkili olduğunu belirtmiştir. Nitekim yapılan analizler sonucunda öz saygının arttığı durumlarda 
girişimcilik niyetinin arttığı da görülmüştür. Bu sonuç Laguna (2013) araştırma bulgusu ile benzerlik göstermektedir. Nitekim söz konusu çalışmada genel olarak benlik saygısının yanı sıra öz yeterliliğin de girişimcilik eylemini ve iş kurma sürecini etkilediğini ortaya koymuştur.

Öz yeterliliğin köprüleyici sosyal sermaye ve girişimcilik niyeti arasındaki aracı etkisine yönelik yapılan analizler neticesinde; öz yeterliliğin bu ilişkide aracı etkiye sahip olduğu görülmüştür. Diğer taraftan araştırmada öz yeterlilik ile girişimcilik niyeti arasındaki ilişkide öz saygının düzenleyici bir etkisinin olduğu tespit edilmiştir. Öz saygının arttığı durumlarda girişimcilik niyetinin arttığı da görülmektedir. Dolayısıyla öz saygının, öz yeterlilik ile girişimcilik niyeti arasındaki pozitif ilişkiyi güçlendirdiği sonucuna ulaşılmıştır. Araştırmanın bu bulgusu Dündar ve Ağca (2007) araştırması ile desteklenmektedir.

Araştırmanın, gerek üniversite yönetimleri ve öğrencilere gerekse de araştırmacılara yönelik birtakım önerileri bulunmaktadır. Öncelikle, üniversite yönetimleri ve ilgili politika yapıcıları üniversitelerde kendine güven ve saygı duyan, öz yeterlilik algısı yüksek, girişimci ruha sahip bireyler yetiştirmeye yönelik eğitsel uygulamalara yer vermelidirler. Bu tarz politika ve uygulamaların benimsenmesi öğrencilerin sosyal sermaye kazanımlarını artıracaktır. Bu bağlamda üniversite yönetimlerinin, öğrenci fikirlerini karar mekanizmalarına aktif bir şekilde dahil etmeleri gerektiği söylenebilir. Her ne kadar öğrenci konsey başkanlıkları aracılığıyla öğrencilerin fikirleri alınıyor olsa da bunun yeterli olmadığı görülmektedir. Bu noktada üniversite yönetimlerinin, düzenli aralıklarla her bir akademik birimin öğrenci temsilcinin bulunduğu toplantılar yaparak öğrenci katılımını artırmalıdırlar. Yine düzenli aralıklarla anketler yapmak suretiyle öğrenci fikirleri değerlendirilmelidir. Halihazırda bunu yapan üniversitelerimiz olmakla birlikte, buradaki en büyük eksilik; bu ankete dayalı görüş ve önerilerin alınmasının titizlikle yapılmaması ve sonuçlarının öğrencilerle paylaşılmamasıdır. Ayrıca öğrenci topluluklarının faaliyetleri teşvik edilmeli ve desteklenmelidir. Öğrencilerin bu faaliyetlere katılması ve etkinlikler organize etmeleri benlik saygılarını artıracağı gibi yetkinlik hissiyatlarını ve girişimcilik becerilerini de geliştirecektir. $\mathrm{Bu}$ doğrultuda öğrencilerinde, sosyal becerilerini artırabilmeleri için; bu tarz etkinliklerin hem organize edeni hem de katılımcısı olmaları gerektiğini söyleyebiliriz.

Araştırmacılara ise ilk olarak, bundan sonraki araştırmalarda öz saygı, öz yeterlilik ve köprüleyici sosyal sermaye değişkenlerini farklı kültürler üzerinden test etmesini öneriyoruz. Kültürel çeşitliliğin çarpıcı sonuçlar verebileceği düşünülmektedir. İkinci olarak, bu değişkenleri farklı bölgelerdeki özel ve devlet üniversitelerindeki öğrenciler üzerinden karşılaştırma yaparak incelemeleri önerilmektedir. Araştırmacıların sosyal sermayenin diğer bir türü olan bağlayıcı sosyal sermaye ile girişimcilik niyeti ilişkisinde iç kontrol odağı, kişilik özellikleri ve sermayeye erişimin aracı ve düzenleyicilik etkisini ele almaları bir diğer öneridir. Son olarak, araştırmacıların öz yeterlilik olgusunu özellikle yabancı alan yazında geçen girişimci öz yeterlilik kavramı olarak ele almalarının Türkçe literatürü zenginleştireceğini söyleyebiliriz. Araştırmanın sınırlılık ve sonuçların genelleştirilebilirliği açısından araştırmanın bazı kısıtları bulunmaktadır. Bunlardan birincisi, araştırmanın örneklem açısından sınırlık arz etmesidir. İkincisi, örneklem grubunun üniversite öğrencileri ile sınırlı olmasıdır. Üçüncü bir kısıt, araştırma örneklem grubunun Doğu Anadolu Bölgesi’ndeki üniversite öğrencilerinden oluşmasıdır.

\section{Kaynakça}

Acs, Z. J., Arenius, P., Hay, M., \& Minniti, M. (2005). Global entrepreneurship monitor: 2004 executive report. http://www.lifelessordinary.com/emails/images/General/GEM-GlobalReport-2004.pdf Erişim: 26.10.2019.

Adler, P., \& Kwon, S. (2002). Social capital: Prospects for a new concept. Academy of Management Review, 27(1), 17-40. 
Ajzen, I. (1988). Attitudes, personality and behavior. Dorsey Press, IL, Chicago.

Ajzen, I. (1991). The theory of planned behavior. Organizational behavior and human decision processes, 50(2), 179-211.

Ajzen, I., \& Driver, B. L. (1992). Application of the theory of planned behavior to leisure choice. Journal of Leisure Research, 24(3), 207-224.

Akyazı, T. E. (2014). Girişimcilik sürecinde sosyal sermaye ve sosyal ağlar ile iç girişimcilik arasındaki ilişki üzerine bir araştırma. (Yayımlanmamış Yüksek Lisans Tezi), Aksaray: Aksaray Üniversitesi Sosyal Bilimler Enstitüsü.

Akyüz, M. (2018). Duygusal emek örgüt temelli öz-sayg1 ve yaşam tatminini etkiler mi?. İşletme Araştırmaları Dergisi, 10(4), 170-186.

Alan, H. (2017). İnsan sermayesi ve kariyer başarısı arasındaki ilişkide sosyal sermayenin rolü: kadın yöneticiler üzerinde bir araştırma. Uluslararası Bilimsel Araştırmalar Dergisi, 2(8), 25-36.

Alparslan, A. M., Taş., M. A., \& Yastıoğlu, S. (2019). Girişimcilik niyeti eğitimle mi artar yoksa kültürel değerlerle mi açıklanır?. Mehmet Akif Ersoy Üniversitesi Sosyal Bilimler Enstitüsü Dergisi, 9(21), 148-161.

Anderson, J. C., \& Gerbing, D. W. (1988). Structural equation modeling in practice: A review and recommended two-step approach. Psychological Bulletin. 103(3), 411.

Ariff, M., Husna, A., Bidin, Z., Sharif, Z., \& Ahmad, A. (2010). Predicting entrepreneurship intention among malay university accounting students in Malaysia. UNITAR $e$ Journal, 6(1).

Arora, P., Haynie, J. M., \& Laurence, G. A. (2013). Counterfactual thinking and entrepreneurial self-efficacy: The moderating role of self-esteem and dispositional affect. Entrepreneurship Theory and Practice, 37(2), 359-385.

Arslan, A., \& Yener, S. (2015). Temel benlik değerlendirmeleri-girişimci kişilik ilişkisinde ençoklamacı karar verme yaklaşımının aracı değişken rolü: Konya örneği. I̧şletme Araştırmaları Dergisi, 7(3), 283-310.

Arslan, E. (2019). Tükenmişlik ve öz yeterlilik inancı arasındaki ilişkide sosyal destek algısının aracı rolü: Akademik personel örneğinde kuşaklar arası farklılık. Ankara: Çankaya Üniversitesi Sosyal Bilimler Enstitüsü (Yayınlanmamış Yüksek Lisans Tezi).

Aşkın, E. Ö., \& Barış, S. (2016). Kadın istihdamında sosyal sermayenin etkisi: Tokat ilinde kadın girişimciler üzerine bir inceleme. Business \& Economics Research Journal, 7(2). 63-82.

Athiyaman, A., Dabson, B., Hamm, G. F., Henderson, J., Holley, J., Hustedde, ve R., Loveridge, S. (2007). Entrepreneurship and Local Economic Development: Lexington Books.

Ayan, A. (2019). Mizah tarzlarının özgüven ve özsaygı düzeyine etkisi: üniversite öğrencileri üzerine bir araştırma. Eskişehir Osmangazi Üniversitesi Sosyal Bilimler Dergisi, 20(1), 85106.

Bagozzi, R. P., \& Yi, Y. (1988). On the evaluation of structural equation models. Journal of the Academy of Marketing Science, 16(1), 74-94.

Bakan, İ., Doğan, İ. F., \& Yılmaz, Y. S. (2017). Çalışanlarda mesleki öz yeterlilik algısı ile örgütsel muhalefet ilişkisi. Organizasyon ve Yönetim Bilimleri Dergisi, 9(2), 54-70. 
Bandura, A. (1977). Self-efficacy: toward a unifying theory of behavioral change. Psychological Review, 84(2), 191-215.

Bandura, A. (1994). Self-efficacy. In V. S. Ramachaudran (Ed.), Encyclopedia of Human Behavior (Vol. 4, pp. 71-81). New York: Academic Press. (Reprinted in H. Friedman [Ed.], Encyclopedia of mental health. San Diego: Academic Press, 1998).

Baron, R. M., \& Kenny, D. A. (1986). The moderator-mediator variable distinction in social psychological research: Conceptual, strategic, and statistical considerations. Journal of Personality and Social Psychology, 51(6), 1173.

Barros, C. P., \& Alves, F. M. P. (2003). Human capital theory and social capital theory on sports management. International Advances in Economic Research, 9(3), 218-226.

Basım, H. N., Korkmazyürek, H., \& Tokat, A. O. (2008). Çalışanların öz yeterlilik algılamasının yenilikçilik ve risk alma üzerine etkisi: kamu sektöründe bir araştırma. Selçuk Üniversitesi Sosyal Bilimler Enstitüsü Dergisi, (19), 121-130.

Baum, J. R., Frese, M., \& Baron, R. A. (2014). Born to be an entrepreneur? Revisiting the personality approach to entrepreneurship. In The Psychology of Entrepreneurship (pp. 7398): Psychology Press.

Bektaş, M., \& Kenar, G. (2017). Meslek yüksekokulu öğrencilerinin kendine saygı düzeyleri ile sosyal uyumları arasındaki ilişki: Mehmet Akif Ersoy Üniversitesi Sosyal Bilimler Yüksekokulunda bir araştırma. Mehmet Akif Ersoy Üniversitesi Sosyal Bilimler Enstitüsü Dergisi, 9(21), 356-368.

Bolat, O. İ. (2011). Öz yeterlilik ve tükenmişlik ilişkisi: lider-üye etkileşiminin aracılık etkisi. Ege Akademik Bakış, 11(2), 255-266.

Bourdieu, P. 1986. The forms of capital. In J. G. Richardson (Ed.), Handbook of theory and research for the sociology of education: 241-258. New York: Greenwood.

Bourdieu, P., \& Wacquant, L. (1992). An invitation to reflexive sociology. Chicago: University of Chicago Press.

Brandstätter, H. (2011). Personality aspects of entrepreneurship: A look at five meta-analyses. Personality and Individual Differences, 51(3), 222-230.

Burke, M., Kraut, R., \& Marlow, C. (2011, May). Social capital on Facebook: Differentiating uses and users. In Proceedings of the SIGCHI Conference on Human Factors in Computing Systems (pp. 571-580). ACM.

Coleman, J. S. (1988). Social capital in the creation of human capital. American Journal of Sociology, 94, S95-S120.

Collins, O. F., \& Moore, D. G. (1964). The enterprising man, prepared by Michigan State University under the Small Business Administration management research grant program. Bureau of Business and Economic Research, Graduate School of Business Administration, Michigan State University.

Coopersmith, S. (1967). The antecedents of self-esteem. W. H. Freeman \& Company, San Francisno.

Craney, T. A., \& Surles, J. G. (2002). Model-dependent variance inflation factor cutoff values. Quality Engineering, 14(3), 391-403.

Çetin, F. (2011). Örgüt içi girişimcilikte öz yeterlilik algısı ve kontrol odağının rolü. Business and Economics Research Journal, 2(3), 69-85. 
Çiçek, B. (2016). Girişimcilik dersinin öğrencilerin girişimcilik eğilimi üzerindeki etkisi: Muş Alparslan Üniversitesi IIBF'de bir araştırma. International Conference on Quality in Higher Education, Sakarya.

Çiçek, B. (2018). Social media entrepreneurship (Sosyal medya girişimciliği). İçtimaiyat Sosyal Bilimler Dergisi, 2(1), 10-17.

Çimen, S. (2007). İlköğretim öğretmenlerinin tükenmişlik yaşantıları ve yeterlik algıları. (Yayınlanmamış Yüksek Lisans Tezi), Kocaeli Üniversitesi Sosyal Bilimler Enstitüsü.

Çolakoğlu, H., \& Çolakoğlu, T. (2016). Üniversitelerdeki girişimcilik eğitimi ile öz yeterlilik algısı ve girişimcilik potansiyeli ilişsisi üzerine bir saha araştırması. Sosyal ve Beşerî Bilimler Araştırmaları Dergisi, 17(37), 70-84.

Davidsson, P. (1991). Continued entrepreneurship: Ability, need, and opportunity as determinants of small firm growth. Journal of Business Venturing, 6(6), 405-429.

Dilmaç, B., \& Ekşi, H. (2008). Meslek yüksekokullarında öğrenim gören öğrencilerin yaşam doyumları ve benlik saygılarının incelenmesi. Selçuk Üniversitesi Sosyal Bilimler Enstitüsü Dergisi, (20), 279-289.

Duman, B., \& Alacahan, O. (2011). Sosyal sermaye/güven boyutunda etniklik. Gaziantep University Journal of Social Sciences, 10(1), 181-208.

Dündar, S., \& Ağca., V. (2007). Afyon Kocatepe Üniversitesi lisans öğrencilerinin girişimcilik özelliklerinin incelenmesine ilişkin ampirik bir çalışma. Hacettepe Üniversitesi İktisadi ve İdari Bilimler Fakültesi Dergisi, 25(1), 121-142.

Ellison, N. B., Steinfield, C., \& Lampe, C. (2007). The benefits of Facebook "friends:" Social capital and college students' use of online social network sites. Journal of ComputerMediated Communication, 12(4), 1143-1168.

Etcheverry, E. (1996). Social capital: A resource for the human capital development of university students. University of Manitoba, Faculty of Education, Doctorate Thesis, Manitoba.

Fornell, C., \& Larcker, D. F. (1981). Evaluating structural equation models with unobservable variables and measurement error. Journal of Marketing Research, 39-50.

Fukuyama, F. (2001). Social capital, civil society and development. Third World Quarterly, 22(1), $7-20$.

Gardner, D. G., \& Pierce, J. L. (1998). Self-esteem and self-efficacy within the organizational context: An empirical examination. Group \& Organization Management, 23(1), 48-70.

Gençtürk, A. \& Memiş, A. (2010). İlköğretim okulu öğretmenlerinin öz yeterlik algıları ve iş doyumlarının demografik faktörler acısından incelenmesi. İlköğretim Online, 9 (3), 10371054.

Güney, S., Akalın, Ç., \& İlsev, A. (2007). Duygusal örgütsel bağl1lık gelişiminde algılanan örgütsel destek ve örgüt temelli öz-saygı. H.Ü. Íktisadi ve İdari Bilimler Fakültesi Dergisi, 25(2). 189-211

Halpern, D. (2005). Social capital. Cornwall: MPG Books.

Han, J., Chu, X., Song, H., \& Li, Y. (2014). Social capital, socioeconomic status and selfefficacy. Applied Economics and Finance, 2(1), 1-10. 
Harter, S., (1990). Causes, correlates, and the functional role of global self-worth: a life span perspective. R.J. Sternberg, J.Jr. Kolligan (Der.), Competence considered: 67-97, Yale University Press, New Haven.

Hu, L. T., \& Bentler, P. M. (1999). Cutoff criteria for fit indexes in covariance structure analysis: Conventional criteria versus new alternatives. Structural Equation Modeling: a Multidisciplinary Journal, 6(1), 1-55.

Iacobucci, D., Saldanha, N., \& Deng, X. (2007). A meditation on mediation: evidence that structural equations models perform better than regressions. Journal of Consumer Psychology, 17(2): 139-153.

Işık, M., Çiçek, B., \& Karakaş, Y. E. (2019). Sosyal sermaye üniversite yaşamından tatmini nasıl etkiler? Uluslararası İktisadi ve İdari Bilimler Kongresi, Şırnak, 608-618.

İlhan, S. (2003). Sosyo-ekonomik bir fenomen olarak girişimciliğin oluşumunu etkileyen başlıca faktörler. Muğla Üniversitesi Sosyal Bilimler Enstitüsü Dergisi(11), 61-79.

İşcan, Ö., \& Çakır, S. (2016). Mentörlük ve psikolojik güçlendirmenin öz yeterlilik algısına etkisi. Süleyman Demirel Üniversitesi İktisadi ve İdari Bilimler Fakültesi Dergisi, 21(1), 115.

Jacobs, J. 1965. The death and life of great American cities. London: Penguin Books.

Jones, S. (1973). Self and interpersonel evaluations: esteem theories versus consistency theories. Psychological Bulletin, 79, 185-199.

Katz, J. A. (2003). The chronology and intellectual trajectory of American entrepreneurship education: 1876-1999. Journal of Business Venturing, 18(2), 283-300.

Koç, M. (2009). Dindarlık ve benlik saygısı arasındaki ilişki. Uludă̆ Üniversitesi İlahiyat Fakültesi Dergisi, 18(1). 473-493.

Kolvereid, L. (1996). Organizational employment versus self-employment: Reasons for career choice intentions. Entrepreneurship Theory and Practice, 20(3), 23-31.

Krueger Jr, N. F., Reilly, M. D., \& Carsrud, A. L. (2000). Competing models of entrepreneurial intentions. Journal of Business Venturing, 15(5-6), 411-432.

Krueger, N. F., \& Carsrud, A. L. (1993). Entrepreneurial intentions: Applying the theory of planned behaviour. Entrepreneurship \& Regional Development, 5(4), 315-330.

Kunz, J., \& Kalil, A. (1999). Self-esteem, self-efficacy, and welfare use. Social Work Research, 23(2), 119-126.

Kuratko, D. F. (2005). The emergence of entrepreneurship education: Development, trends, and challenges. Entrepreneurship Theory and Practice, 29(5), 577-597.

Laguna, M. (2013). Self-efficacy, self-esteem, and entrepreneurship among the unemployed. Journal of Applied Social Psychology, 43(2), 253-262.

Leana-Taşcılar, M. Z., \& Kanlı, E. (2014). Üstün zekâlı ve normal gelişim gösteren çocukların, mükemmeliyetçilik ve öz-sayg1 düzeylerinin incelenmesi. Ankara Üniversitesi Eğitim Bilimleri Fakültesi Dergisi, 47(2), 1-20.

Liñán, F., \& Chen, Y. W. (2009). Development and cross-cultural application of a specific instrument to measure entrepreneurial intentions. Entrepreneurship Theory and Practice, 33(3), 593-617. 
Liñán, F., Rodríguez-Cohard, J. C., \& Rueda-Cantuche, J. M. (2011). Factors affecting entrepreneurial intention levels: a role for education. International Entrepreneurship and Management Journal, 7(2), 195-218.

Luszczynska, A., Scholz, U. \& Schwarzer, R. (2005). The general self-efficacy scale: multicultural validation studies. The Journal of Psychology, 139(5), 439-457.

Maddux, J. E., Sherer, M., \& Rogers, R. W. (1982). Self-efficacy expectancy and outcome expectancy: Their relationship and their effects on behavioral intentions. Cognitive Therapy and Research, 6(2), 207-211.

Mallinckrodt, B., Abraham, W. T., Wei, M., \& Russell, D. W. (2006). Advances in testing the statistical significance of mediation effects. Journal of Counseling Psychology, 53(3), 372.

McClelland, D. C. (1962). Business drive and national achievement. Harvard Business Review, 40(4), 99-112.

McMullan, W., \& Gillin, L. (2001). Entrepreneurship education in the nineties: Revisited. Entrepreneurship Education: A Global View, 57-77.

Mehrotra, S., \& Chaddha, U. (2013). A co-relational study of protective factors, resilience and selfesteem in pre medical dropouts, International Journal of Humanities and Social Science Invention, 2(9), 103-106.

Mert, İ. S., \& Şen, C. (2019). Örgütsel destek, örgütsel adalet ve öz kendilik değerlendirmesinin psikolojik sermaye üzerindeki etkisi. Pamukkale Üniversitesi Sosyal Bilimler Enstitüsü Dergisi, 36. 213-231.

Meydan, C. H. (2011). İş tatmini ve öz yeterliliğin örgüt içi girişimciliğe etkisi: Kamu sektöründe bir araştırma. Çukurova Üniversitesi Sosyal Bilimler Enstitüsü Dergisi, 20(1), 25-40.

Muzyka, D., De Koning, A., \& Churchill, N. (1995). On transformation and adaptation: Building the entrepreneurial corporation. European Management Journal, 13(4), 346-362.

Nahapiet, J., \& Ghoshal, S. (1998). Social capital, intellectual capital, and the organizational advantage. Academy of Management Review, 23(2), 242-266.

Oosterbeek, H., Van Praag, M., \& Ijsselstein, A. (2010). The impact of entrepreneurship education on entrepreneurship skills and motivation. European Economic Review, 54(3), 442-454.

Özdevecioğlu, M., \& Cingöz, A. (2009). Sosyal girişimcilik ve sosyal girişimciler: Teorik çerçeve. Erciyes Üniversitesi İktisadi ve İdari Bilimler Fakültesi Dergisi, 32, 81-95.

Pajares, F. (1996). Self-efficacy beliefs in academic settings. Review of Educational Research, 66(4), 543-578.

Putnam, R. (2000). Bowling alone: The collapse and revival of American community. New York, NY: Simon \& Schuster.

Putnam, R. D., Leonardi, R., \& Nanetti, R. Y. (1994). Making democracy work: Civic traditions in modern Italy. Princeton university press.

Rauch, A., \& Frese, M. (2007). Let's put the person back into entrepreneurship research: A metaanalysis on the relationship between business owners' personality traits, business creation, and success. European Journal of Work and Organizational Psychology, 16(4), 353-385.

Reisoğlu, S. \& Yazıcı, H. (2017). Üniversite öğrencilerinin öznel iyi oluşlarını yordamada beş faktör kişilik özellikleri, mizah tarzları ve duygusal zekanın rolü. Journal of History Culture and Art Research, 6(4). 888-912. 
Rosenthal, S. A., Hooley, J. M., Montoya, R. M., van der Linden, S. L., \& Steshenko, Y. (2019). The narcissistic grandiosity scale: A measure to distinguish narcissistic grandiosity from high self-esteem. Assessment, 1-21.

Schmitt-Rodermund, E. (2004). Pathways to successful entrepreneurship: Parenting, personality, early entrepreneurial competence, and interests. Journal of Vocational Behavior, 65(3), 498-518.

Schunk, D. H. (1991). Self-efficacy and academic motivation. Educational Psychologist, 26(3-4), 207-231.

Schwarzer, R., Mueller, J., \& Greenglass, E. (1999). Assessment of perceived general self-efficacy on the Internet: Data collection in cyberspace. Anxiety, Stress and Coping, 12(2), 145-161.

Sequeira, J., Mueller, S. L., \& McGee, J. E. (2007). The influence of social ties and self-efficacy in forming entrepreneurial intentions and motivating nascent behavior. Journal of Developmental Entrepreneurship, 12(03), 275-293.

Sexton, D. L., \& Bowman, N. (1984). Personality inventory for potential entrepreneurs: Evaluation of a modified JPI/PRF-E test instrument. Frontiers of Entrepreneurship Research, 513528.

Sexton, D. L., \& Bowman, N. B. (1983). Comparative entrepreneurship characteristics of students: Preliminary results. Frontiers of Entrepreneurship Research, 3, 213-232.

Shane, S. (2007). A general theory of entrepreneurship, the individual-opportunity Nexus, Edward Elgar Publishing, UK.

Sivo, S. A., Fan, X., Witta, E. L., \& Willse, J. T. (2006). The search for "optimal" cutoff properties: Fit index criteria in structural equation modeling. The Journal of Experimental Education, 74(3), 267-288.

Steinfield, C., Ellison, N. B., \& Lampe, C. (2008). Social capital, self-esteem, and use of online social network sites: A longitudinal analysis. Journal of Applied Developmental Psychology, 29(6), 434-445.

Steinfield, C., Ellison, N. B., \& Lampe, C. (2008). Social capital, self-esteem, and use of online social network sites: A longitudinal analysis. Journal of Applied Developmental Psychology, 29(6), 434-445.

Şan, M., \& Şimşek, R. (2011). Sosyal sermaye kavramının tarihsel-sosyolojik arkaplanı. Akademik Incelemeler Dergisi (AID), 6(1), 88-110.

Tabachnick, B. G., Fidell, L. S., \& Ullman, J. B. (2007). Using multivariate statistics (Vol. 5). Boston, MA: Pearson.

Thompson, G., Buch, R., \& Glasø, L. (2018). Low-quality LMX relationships, leader incivility, and follower responses. Journal of General Management, 44(1), 17-26.

Tokat, A. O. (2007). Öz yeterlilik algısının performans ve girişimciliğe etkisi: uygulamalı bir araştırma. Yayımlanmamış Yüksek Lisans Tezi, Ankara: Kara Harp Okulu Savunma Bilimleri Enstitüsü.

Toprak, E., \& Bozgeyikli, H. (2011). Öğretmen adaylarının sosyal sermaye düzeylerinin karşılaştırmalı incelenmesi (Erciyes Üniversitesi Örneği). Erciyes Üniversitesi Sosyal Bilimler Enstitüsü Dergisi, 1(31), 125-147. 
Van Gelderen, M., Brand, M., van Praag, M., Bodewes, W., Poutsma, E., \& Van Gils, A. (2008). Explaining entrepreneurial intentions by means of the theory of planned behaviour. Career Development International, 13(6), 53.

Wu, S. Y., Wang, S. T., Liu, F., Hu, D. C., \& Hwang, W. Y. (2012). The influences of social selfefficacy on social trust and social capital-a case study of Facebook. Turkish Online Journal of Educational Technology-TOJET, 11(2), 246-254.

Yetim, N. (2002). Sosyal sermaye olarak kadın girişimciler: Mersin örneği. Ege Akademik Bakış Dergisi, 2(2), 79-92.

Y1lmaz, R., \& Meçik, O. (2017). Teorideki dönüşüm: paranın nötrleşmesi ve sosyal sermayenin güçlenmesi. Aksaray Üniversitesi İktisadi ve İdari Bilimler Fakültesi Dergisi, 9(1), 23-38.

Yüner, B. (2018). Örgüt temelli öz sayg1 ile duygusal örgütsel bağl1lığa ilişkin öğretmen görüşleri. Ankara Üniversitesi Eğitim Bilimleri Fakültesi Özel Eğitim Dergisi, 19(4), 777799. 